\title{
The Role of the Tumor Microenvironment in Developing Successful Therapeutic and Secondary Prophylactic Breast Cancer Vaccines
}

\author{
Benjamin Gordon ${ }^{1,2, *(1)}$ and Vijayakrishna K. Gadi ${ }^{3}$ \\ 1 Department of Physiology and Biophysics, University of Illinois College of Medicine, Chicago, IL 60612, USA \\ 2 Medical Scientist Training Program, University of Illinois College of Medicine, Chicago, IL 60612, USA \\ 3 Division of Hematology and Oncology, University of Illinois Cancer Center, University of Illinois at Chicago, \\ Chicago, IL 60612, USA; vkgadi@uic.edu \\ * Correspondence: bgordo6@uic.edu
}

Received: 25 August 2020; Accepted: 13 September 2020; Published: 14 September 2020

\begin{abstract}
Breast cancer affects roughly one in eight women over their lifetime and is a leading cause of cancer-related death in women. While outcomes have improved in recent years, prognosis remains poor for patients who present with either disseminated disease or aggressive molecular subtypes. Cancer immunotherapy has revolutionized the treatment of several cancers, with therapeutic vaccines aiming to direct the cytotoxic immune program against tumor cells showing particular promise. However, these results have yet to translate to breast cancer, which remains largely refractory from such approaches. Recent evidence suggests that the breast tumor microenvironment (TME) is an important and long understudied barrier to the efficacy of therapeutic vaccines. Through an improved understanding of the complex and biologically diverse breast TME, it may be possible to advance new combination strategies to render breast carcinomas sensitive to the effects of therapeutic vaccines. Here, we discuss past and present efforts to advance therapeutic vaccines in the treatment of breast cancer, the molecular mechanisms through which the TME contributes to the failure of such approaches, as well as the potential means through which these can be overcome.
\end{abstract}

Keywords: breast cancer; cancer vaccines; tumor microenvironment; checkpoint inhibitors

\section{Introduction}

Immunotherapy has revolutionized the treatment paradigm for several cancers. While such approaches show promise in many solid tumors [1-7], progress for immunotherapy in breast cancer has been difficult [8]. This is particularly true for therapeutic vaccines, which have yet to show significant clinical efficacy in breast cancer [9]. While several barriers to efficacy have been suggested, there is a growing body of evidence supporting the tumor microenvironment (TME) as an important consideration in breast cancer immunotherapy [10].

The TME has several roles in breast cancer etiology [11,12], and comprises heterogeneous populations of immune cells, fibroblasts, vascular endothelial cells, and extracellular matrix at both primary and metastatic sites [11]. Accordingly, the breast TME is often highly immunosuppressive, contributing to the relative failure of several immunotherapies $[13,14]$. Here, we discuss attempts to advance therapeutic vaccines in breast cancer, as well as factors within the breast TME that serve as barriers to their therapeutic efficacy and the potential means through which they can be overcome (Figure 1). 


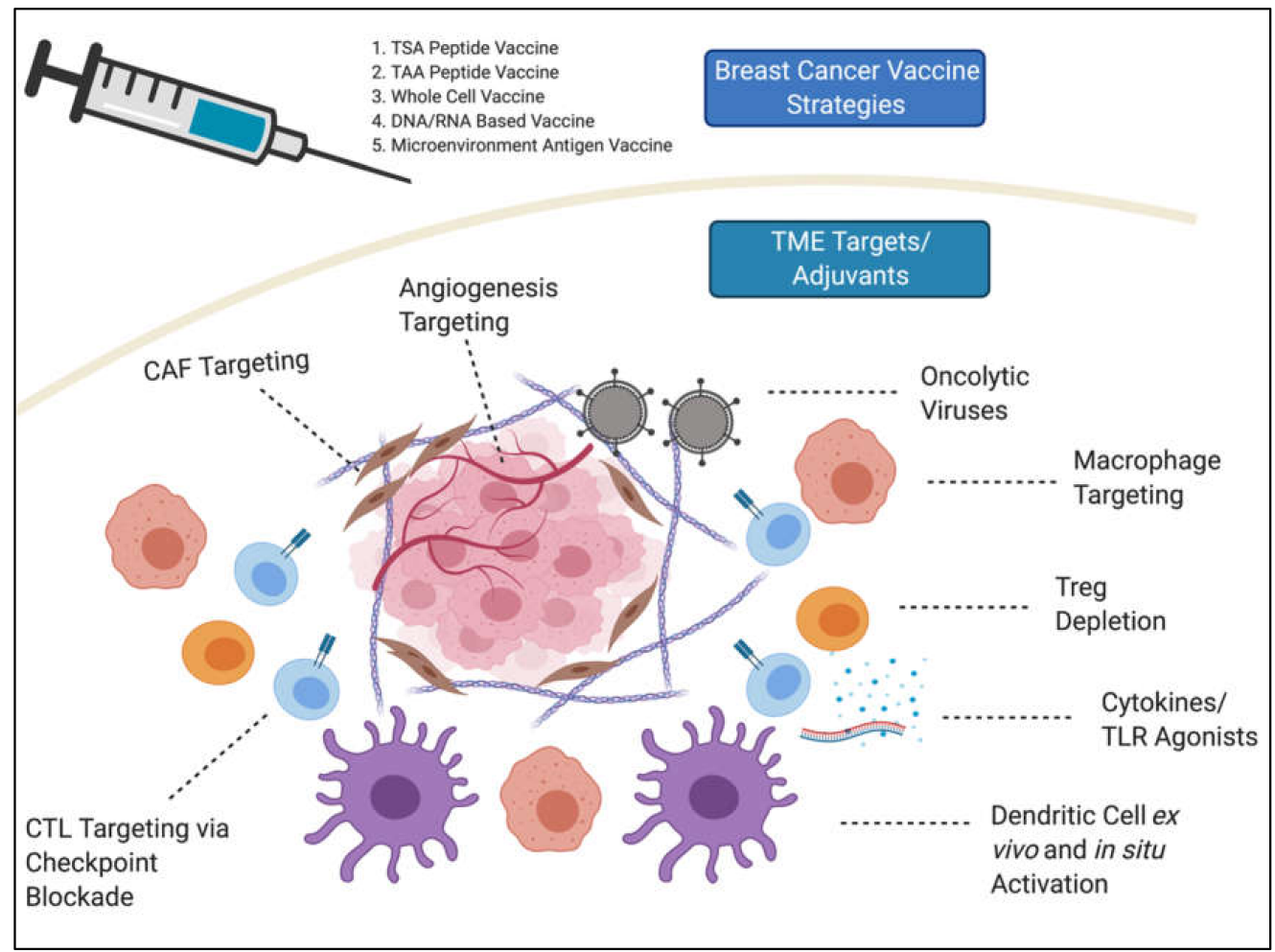

Figure 1. Awakening the tumor microenvironment as a means to increase efficacy of therapeutic breast cancer vaccines. Peptide, nucleotide, and whole cell-based vaccines have been tested for many years but have failed in the clinic partly because of an immunosuppressive tumor microenvironment (TME). Increased understanding of the TME and novel therapeutics to increase anti-tumor immune properties have increased vaccine promise in pre-clinical models. This paradigm is currently being tested in clinical trials. TME, tumor microenvironment; TSA, tumor specific antigen; TAA, tumor associated antigen; CAF, cancer associated fibroblast; Treg, regulatory T-cells; CTL, cytotoxic T lymphocytes; TLR, toll-like receptor. (Figure created with BioRender).

\section{Breast Cancer Vaccines and the Microenvironment Hurdle}

The goal of breast cancer vaccines is to induce a robust specific immune attack against antigens related to a patient's tumor [15]. Tumor specific antigens (TSA) are antigens restricted to the tumor, such as neoantigens, cancer-testis antigens, and tumor-virus antigens, which have been discussed elsewhere [16]. New sequencing, quality control analysis, and bioinformatic pipelines have now made it possible to predict patient overall survival (OS) based on neoantigen binding affinity to MHC I and MHC II molecules [17]. This understanding opens the opportunity for personalized approaches to gauge immunogenic potential in individual patients. Tumor associated antigens (TAA), as opposed to TSAs, can be found in normal tissue, but are overexpressed in the tumor. For breast cancer, common TAAs include human epidermal growth factor-2/neu (HER2/neu), mucin-1 (MUC1), p53, carcinoembryonic antigens (CEA), and human telomerase reverse transcriptase (hTERT) [16]. Both TSAs and TAAs have been evaluated for suitability towards vaccine development in breast cancer in preclinical and early-clinical studies in order to elicit a CD8+ T-cell (cytotoxic T lymphocyte, or CTL) and Natural Killer Cell (NKT) response.

DNA, RNA, and whole cell vaccines are other emerging therapeutic strategies against breast cancer, which are summarized in Table 1 . In addition to the antigen presentation from vaccines, damage associated molecular patterns (DAMPS), which are certain nucleic acids or proteins emitted from dying cells, can bind toll like receptors (TLRs) of antigen presenting cells (APCs) of the innate immune system to trigger Type I interferon (IFN) responses [13]. DAMPs can be augmented by radiation therapy or other cytotoxic therapies, as will be discussed more below. 
Table 1. BC Vaccine Types.

\begin{tabular}{cl}
\hline Class & \multicolumn{1}{c}{ Examples } \\
\hline TSA Peptide Vaccines & Cancer-testis antigens, Neoantigens, Tumor virus antigens \\
\hline TAA Peptide Vaccines & $\begin{array}{l}\text { HER2/neu (eg E75, NeuVax), MUC1, p53, CEA, hTERT, Folate Binding Proteins } \\
\left(\text { E39/J65), sialyl Lewis }{ }^{\text {a }}\right.\end{array}$ \\
\hline DNA Vaccines & $\begin{array}{l}\text { Rat HER2/neu, Human mammaglobin-A (SCGB2A2), } \\
\text { CD105/Yb-1/SOX2/CDH3/MDM2-polyepitpope plasmid, neoantigen DNA, } \\
\text { pUMVC3-IGFBP2-HER2-IGF1R plasmid, pNGVL3-hICD plasmid }\end{array}$ \\
\hline RNA Vaccines & $\begin{array}{l}\text { IVAC_W_bre1_uID and IVAC_M_uID (IVAC MUTANOME), Alphavirus-like replicon } \\
\text { particles with HER2 RNA }\end{array}$ \\
\hline Whole Cell Vaccines & Dendritic Cell (DC) vaccines, Autologous or allogenic tumor vaccines \\
\hline Microenvironment Targeting Vaccines & Angiogenesis-targeting vaccines, Fibroblast-targeting vaccines \\
\hline
\end{tabular}

Most breast cancer (BC) vaccine development has focused on therapeutic use and/or secondary prophylaxis. While breast cancer vaccines show promise in preclinical experiments and appear to be safe to human patients [18], clinical responses are usually limited. In addition to tumor-intrinsic resistance mechanisms, the cancer microenvironment is a major reason for the frustrating clinical results indicating that vaccines have yet to help patients in a meaningful way [14].

Whereas antibody titers are major determinants for prophylactic pathogen vaccines, breast cancer vaccines aim to induce a sterile cytotoxic cell mediated effect against the tumor. Even with proper antigen presentation, however, the microenvironment can hinder proper vaccine mediated CD8+ T-cell responses in multiple ways. First, there is a physical barrier presented by the microenvironment. The stroma and extracellular matrix present a physical obstacle to T-cell infiltration [19,20]. Moreover, pathological tumor vasculature may hinder proper leukocyte infiltration into the tumor, as adhesion molecules and chemokines present in physiological inflammation may not be available [21]. In addition to physical barriers, the cellular makeup of the TME can be immunosuppressive, with an immune-inhibiting subset of T-cells, macrophages, dendritic, and myeloid derived suppressor cells (MDSCs) blunting an attack [11]. During effective responses to microbes, the innate and adaptive immune systems synergize for a proper immune attack. However, in the TME, there is an anti-inflammatory, pro-angiogenic, matrix-deposition, and tissue remodeling state in which the adaptive and innate cells of the BC niche are not able to promote beneficial immune responses. From an evolutionary point of view, this type of regulation in sterile immunity prevents autoimmune disease. However, for BC vaccines, an inflammatory TME is needed for sterile immunity against breast cancer cells. There are currently preclinical studies and clinical trials ongoing to circumvent this problem in two significant ways:

1. In situ TME modulation strategy: An emerging strategy to potentiate the effects of breast cancer vaccines is to use a priming agent to reprogram a highly immunosuppressive TME to take on a more pro-inflammatory state, thereby enhancing the presentation of tumor antigen. This process aims to take advantage of the physiologic response to microbial infections, in which pathogen-associated molecular patterns (PAMPs) are recognized by innate immune cells via by toll-like receptors (TLRs) and other pathogen sensing receptors. Parallel to the innate immune response, these invading microbes are also endocytosed, processed, and presented by APCs, allowing for interface between innate and adaptive immune systems. Antigen is presented on either MHC class I or MHC class II molecules, allowing for recognition by CD8+ or CD4+ T-cells, respectively. This is the first step in effector T-cell activation, which also requires additional co-stimulatory signals including association between the CD80 ligand on APCs and the CD28 receptor on T-cells. Cancer vaccines rely on a similar series of events to activate T-cell immunity but lack the infectious etiology to effectively initiate the above cascade. Hence, in the absence of associated strategies to foster antigen presentation to tumor-reactive T-cells within the TME, the effects of therapeutic vaccines may be limited. Several strategies to address this have been explored in the setting of therapeutic vaccines, including depletion of immunosuppressive cell subsets such as Tregs, additional stimulation of professional APCs, suppression of T-cell "stop signals" (i.e., PD-1/PD-L1, CTLA-4) via checkpoint inhibitors, and a molecular "mimic" of a microbial infection using either TLR agonists or oncolytic viruses. Recent progress for such approaches is discussed in detail below. 
2. TME antigen targeting strategy: An additional strategy for breast vaccination is to use antigens derived from the surrounding tumor microenvironment rather than from tumor cells themselves. One potential advantage of this strategy is that resident-cells in the TME are likely more genomically stable than breast cancer cells themselves, which often display deficits in DNA repair. This genomic stability may prevent further immunoediting, and the eventual evasion from CTL attack through changes in the antigen repertoire. Several potential targets for therapeutic vaccines have been proposed, namely those related to the tumor vasculature and stromal cells, as summarized below.

\section{T-Cells}

Tumor infiltrating lymphocytes (TILs) are a significant predictor of prognosis in patients with breast cancer, especially for those with triple negative breast cancer (TNBC, ER-PR- without HER2 amplification) or certain ER+ subtypes [22-24]. However, infiltration of the tumor by CD8+ T-cells is insufficient by itself to immunologically clear the tumor. T-cells in the tumor microenvironment undergo exhaustion, senescence, and/or anergy, as CD8+ T-cells are not receiving proper co-stimulation or undergo chronic stress and ageing. Studies of CD8+ T-cell subset analysis highlights the heterogeneity of CTLs and informs on their various functions. For instance, CD39+ CD8+ T-cells are exhausted CTLs in BC that have compromised IL-2 and TNF $\alpha$ production, which foster primary and metastatic tumor growth [25]. CD39 is an ATP ectonucleotidase, which hydrolyzes ATP and suppresses an ATP-driven pro-inflammatory state. Moreover, using single-cell (sc) RNA-seq to profile CTLs within the breast cancer microenvironment, a large proportion express an exhausted phenotype [26,27]. The proper identification of effector CD8+ T-cells, as opposed to pure quantification of CD8+ TILs, may be instrumental in identifying targets for immunotherapy. Savas et al., for instance, used scRNA-seq to identify tissue-resident memory CD103+ CD8+ T-cells that are associated with improved prognosis and increased immunosurveillance [26].

$B C$ vaccines are a poor therapeutic without their main ally: effective and healthy T-cells. Checkpoint signaling, such as through PD-1/PD-L1, is a key characteristic of CD8+ T-cell exhaustion. Moreover, infiltration of suppressive immune cells into the TME can further contribute to an underwhelming anti-tumor response. Therefore, two strategies that have been employed to get around these hurdles is (1) checkpoint blocking antibodies as a BC vaccine adjuvant and (2) strategies that create a pro-inflammatory TME by regulatory T-cell (Treg) depletion.

\subsection{Checkpoint Blockades as Adjuvants to BC Vaccines}

As discussed, a highly immunosuppressive TME impedes the effector function of tumor infiltrating lymphocytes. Thus, the T-cells residing in the breast TME are frequently anergic or functionally exhausted $[25,28]$. Beyond functioning as surrogate markers of T-cell exhaustion, immune checkpoints such as PD-1/PD-L1 have important roles in maintaining the immunosuppressive niche in the TME, and there is emerging evidence suggesting that some $\mathrm{BC}$ patients may derive clinical benefit from immune checkpoint inhibitors. For instance, the combination of Atezolizumab (Tecentriq) and nab-paclitaxel has now been approved for PD-L1+ TNBC [29]. While tumor PD-L1 positivity by immunohistochemistry has long been considered the gold standard for predicting responses to PD-1/PD-L1 inhibition, there is now mounting evidence that PD-1/PD-L1 expression on tumor infiltrating lymphocytes may also have predictive value, though this requires further investigation [30,31].

Beyond the expression of PD-1/PD-L1, there are several other clinically useful predictors of responses to immune checkpoint inhibition, most notably a high microsatellite instability phenotype (MSI-H) and/or an increased tumor mutation burden (TMB). Mismatch repair deficiency has been shown to strongly predict responses to immune checkpoint inhibition in a variety of solid tumor types [32]. In cases of high MSI-H and TMB, the increased mutational burden leads to a corresponding increase in associated neoantigens, which is a potentially significant consideration when predicting checkpoint blockade response. While MSI-H tumors have shown favorable responses to immune checkpoint inhibition in pan cancer trials [33], it is important to note that MSI-H is uncommon in 
$\mathrm{BC}$, and may have limited utility in stratifying BC patients for therapy [34]. Although TMB is less established as a predictor of drug responses in $\mathrm{BC}$ as in other cancers [35], there is emerging evidence that TMB has significant impact in directing the local immune responses in TNBC [36]. While TMB scoring is still not well established in BC clinical practice, an intermediate or high TMB score across all BC subtypes was associated with an increase in tumor infiltrating CTLs and, rather interestingly, DNA damage repair gene mutations (BRCA1/2) [37]. This is an ongoing area of research, and murine models of TMB-high TNBC are showing early promise in substantiating TMB status as clinically useful predictor of checkpoint blockade response [38].

Recent preclinical and clinical progress testing immune checkpoint inhibitors in BC has compelled researchers and clinicians to combine these approaches with therapeutic vaccines. There are several ongoing clinical trials using anti-PD-1 pembrolizumab (Keytruda) [39], anti-PD-L1 avelumab (Bavencio), anti-PD-L1/TGF- $\beta$ trap fusion M7824, anti-CTLA-4 tremelimumab, and anti-PD-1 durvalamab (Imfinzi) as adjuvants to various $B C$ vaccines (see Table 2). In the clinical setting, for instance, a p53-expressing viral-based vaccine with pembrolizumab adjuvant identified a marked increase in p53-specific CD8+ effector T-cells with clinical response in two patients, one of whom had TNBC [39].

Functioning as vaccine adjuvants, drugs targeting checkpoint molecules have shown remarkable promise in the preclinical setting [40-42]. In one study, a soluble PD-1-based TWIST1 DNA vaccine in conjunction with anti-CTLA-4 antibody significantly reduced tumor growth and lung metastasis, presumably by increasing IFN- $\gamma+\mathrm{TNF} \alpha+\mathrm{CD} 8+\mathrm{T}$-cells [43]. Many other vaccine checkpoint blocking adjuvant combinations similarly increased CD8+ T and NK cell effector infiltration while causing tumor regression using different $\mathrm{BC}$ vaccine and adjuvant strategies [40,41,44-47]. A 4T1 model using autologous whole cell vaccine and anti-PD-1 antibodies not only increased CD8+ T-cell infiltration, but also reduced immunosuppressant CD68+ tumor associated macrophages (TAMs) and Gr-1+ CD11b+ myeloid derived suppressor cells (MDSCs) [42]. TAMs can be M1 (pro-inflammatory) or M2 (pro-tumorigenic) polarized; anti-PD-1 significantly reduced M2 polarized TAMs while favoring proinflammatory state as shown by increased IFN- $\gamma+\mathrm{CD} 68+$ cells. In yet another demonstration of how checkpoint blockade can lead to a pro-inflammatory TME, Hassannia and colleagues downregulated PD-1 and PD-L1 via siRNA-based nanoparticles and used a dendritic-based BC vaccine to eliminate Treg cells in the TME [46]. Therefore, not only do checkpoint adjuvants stimulate T effector cells, but they regulate immunosuppressive cells in the TME.

Interestingly, many of the $\mathrm{BC}$ vaccine/checkpoint blockade combinations also significantly affected CD4+ helper T-cell contribution in the TME. Similar to TAM polarization, CD4+ helper T-cells can be Th1 (proinflammatory) or Th2 (pro-tumorigenic) polarized in the TME. When CD4+ T-cells were specifically deleted in a murine HER2 + BC model using a HER2-based dendritic vaccine in combination with anti-PD-1 and anti-PD-L1, the efficacy of the therapy was compromised [47]. Without CD4+ T-cell abrogation, the researchers showed that there was a strong IFN- $\gamma$ based Th1 polarized response in the combination therapy group. This strategy led to a remarkable $400 \%$ survival rate in treated group compared to control mice. Of note, the CD4/CD8 T-cell response was dependent on MHC class used in the vaccine production, as MHC I based vaccine duly restricted the immune response to CD8+ T-cells. A high CD4/CD8 ratio is associated with worse patient prognosis in BC settings [48]. Similar results with CD4+ T-cell depletion and reduced therapeutic response were observed when a group used a stimulator of interferon genes (STING) agonist alongside OX40R agonist with PD-L1 blockade in a NT2.5 breast cancer model [49]. Using a different strategy, another group showed that combination therapy of autologous whole cell vaccination with anti-PD-1 increased Th1 bias [42], while the aforementioned TWIST1-sPD-1/anti-CTLA-4 study also showed increased Th1-like CD4+ T-cells and decreased Th2-like CD3+ cells [43]. However, some studies with checkpoint blockade vaccine strategies showed CD4+ T-cell depletion had little bearing on CD8+ T-cell function [44,45]. Future studies will need to further characterize CD4 and CD8 T-cell phenotypes to determine their activity and function in their response to $\mathrm{BC}$ vaccines and checkpoint blockade adjuvants. 
Table 2. BC Vaccine Clinical Trials that Target TME.

\begin{tabular}{|c|c|c|c|c|}
\hline Clinical Trial ID & BC Type & Vaccine Description & Microenvironment Target & Phase \\
\hline NCT03362060 & mTNBC (HLA-A2+) & $\begin{array}{l}\text { PVX-410 (Multi-peptide Vaccine) + Pembrolizumab } \\
\text { (Anti-PD-1) }\end{array}$ & Checkpoint Molecules & I (recruiting) \\
\hline NCT03066947 & Local or $\mathrm{mBC}$ & $\begin{array}{l}\text { SV-BR-1-GM (GM-CSF Secreting BC Cell Line) + } \\
\text { Cyclophosphamide }\end{array}$ & Dendritic Cells and Other Cells (GM-CSF); Tregs & I/II (completed) \\
\hline NCT02479230 & BC & $\begin{array}{c}\text { Type I Polarized Autologous DC Vaccine with Tumor } \\
\text { Blood Vessel Antigen-Derived Peptides } \\
\end{array}$ & Dendritic Cells; Angiogenesis & I (completed) \\
\hline NCT01730118 & HER2+ BC & HER2-pulsed DC Vaccination & Dendritic Cells & I (completed) \\
\hline NCT02018458 & TNBC & $\begin{array}{l}\text { Cyclin B1/WT-1/CEF-loaded DC Vaccine + } \\
\text { Chemotherapy (Varied) }\end{array}$ & Dendritic Cells & III (completed) \\
\hline NCT02063724 & HER2+ BC & HER2-pulsed DC Vaccine & Dendritic Cells & I (active, not recruiting) \\
\hline NCT02061423 & HER2+ BC & HER2-pulsed DC Vaccine + Trastuzumab & Dendritic Cells & I (active, not recruiting) \\
\hline NCT02061332 & DCIS & HER2-pulsed DC Vaccine & Dendritic Cells & I/II (completed) \\
\hline NCT02643303 & BC & $\begin{array}{l}\text { Poly-ICLC in situ Vaccine + Durvalumab (Anti-PD-1) + } \\
\text { Tremelimumab (Anti-CTLA-4) }\end{array}$ & TLR; Checkpoint Molecules & I/II (recruiting) \\
\hline NCT00791037 & HER2+ BC & $\begin{array}{c}\text { HER2 Peptide Vaccine + Aargramostim } \\
+ \text { Cyclophosphamide + Adoptive HER2 Specific T-cells }\end{array}$ & Dendritic Cells and Other Cells (GM-CSF); T-cells; Tregs & I/II (completed) \\
\hline NCT02140996 & $\mathrm{BC}$ & Ad-sig-hMUC1/ecdCD40L Vector Vaccine & APCs (CD40L) & I (recruiting) \\
\hline NCT02593227 & $\mathrm{BC}$ & $\begin{array}{c}\text { Folate Receptor Alpha Peptide Vaccine + GM-CSF + } \\
\text { Cyclophosphamide }\end{array}$ & Dendritic Cells and Other Cells (GM-CSF); Tregs & II (active, not recruiting) \\
\hline NCT02636582 & DCIS & $\begin{array}{l}\text { NeuVax (Nelipepimut-S Peptide Vaccine with } \\
\text { Sargramostim Adjuvant) }\end{array}$ & Dendritic Cells and Other Cells (GM-CSF) & II (active, not recruiting) \\
\hline NCT01660529 & $\mathrm{mBC}$ & $\begin{array}{l}\text { hTERT/survivin/CMT Multipeptide Vaccine + } \\
\text { Basiliximab (anti-CD25) }\end{array}$ & Tregs & I (completed) \\
\hline NCT01570036 & HER2 low BC & $\begin{array}{l}\text { NeuVax (Nelipepimut-S Peptide Vaccine with } \\
\text { Sargramostim Adjuvant) + Trastuzumab }\end{array}$ & Dendritic Cells and Other Cells (GM-CSF) & II (completed) \\
\hline NCT04215146 & ER+ HER2- mBC & $\begin{array}{c}\text { Pelareorep (Reovirus-based Therapy) + Nab-paclitaxel + } \\
\text { Avelumab (Anti-PD-L1) }\end{array}$ & Multi-target (Oncolytic Virus); Checkpoint Molecules & II (recruiting) \\
\hline NCT02779855 & TNBC & $\begin{array}{l}\text { Talimogene Laherparepvec (Herpes Virus-based } \\
\text { Therapy) + Nab-paclitaxel }\end{array}$ & Multi-target (Oncolytic Virus) & I/II (active, not recruiting) \\
\hline NCT04301011 & TNBC & $\begin{array}{l}\text { TBio-6517 (Vaccinia Virus-based Therapy) + } \\
\text { Pembrolizumab (Anti-PD-1) }\end{array}$ & Multi-target (Oncolytic Virus); Checkpoint Molecules & I/II (recruiting) \\
\hline NCT03740256 & HER2+ BC & $\begin{array}{l}\text { CAdVEC (Adenovirus-based Therapy) + Autologous } \\
\text { CAR Viral Specific T-cells }\end{array}$ & Multi-target (Oncolytic Virus); T-cells & I (not yet recruiting) \\
\hline NCT02826434 & TNBC & $\begin{array}{l}\text { PVX-410 (Multi-peptide Vaccine) + Durvalumab } \\
\text { (Anti-PD-L1) }\end{array}$ & Checkpoint Molecules & I (active, not recruiting) \\
\hline
\end{tabular}


Table 2. Cont.

\begin{tabular}{|c|c|c|c|c|}
\hline Clinical Trial ID & BC Type & Vaccine Description & Microenvironment Target & Phase \\
\hline NCT02276300 & $\mathrm{HER} 2+\mathrm{BC}$ & $\begin{array}{c}\text { HER2 Peptide Vaccine + Sargramostim } \\
\text { + Cyclophosphamide } \\
\text { + Imiquimod }\end{array}$ & Dendritic Cells and Other Cells (GM-CSF); Tregs, TLR & I (completed) \\
\hline NCT02297698 & HER2+ BC & $\begin{array}{l}\text { NeuVax (Nelipepimut-S Peptide Vaccine with } \\
\text { Sargramostim Adjuvant) + Trastuzumab }\end{array}$ & Dendritic Cells and Other Cells (GM-CSF) & II (active, not recruiting) \\
\hline NCT00986609 & TNBC & MUC-1 Peptide Vaccine + Poly-ICLC & TLR & I (completed) \\
\hline NCT02019524 & $\mathrm{BC}$ & $\begin{array}{c}\text { Folate Binding (E39 and J65) Peptide Vaccine + } \\
\text { Sargramostim }\end{array}$ & Dendritic Cells and Other Cells (GM-CSF) & I/II (completed) \\
\hline NCT00524277 & HER2+ BC & $\begin{array}{l}\text { HER2 (GP2) Peptide Vaccine + Modified HER2 (AE37) } \\
\text { Peptide Vaccine + Sargramostim }\end{array}$ & Dendritic Cells and Other Cells (GM-CSF) & II (completed) \\
\hline NCT00971737 & $\mathrm{BC}$ & $\begin{array}{l}\text { Allogenic GM-CSF-Secreting Whole Tumor Cell Vaccine } \\
\text { + Cyclophosphamide }\end{array}$ & Dendritic Cells and Other Cells (GM-CSF); Tregs & II (completed) \\
\hline NCT03066947 & $\mathrm{BC}$ & $\begin{array}{l}\text { SV-BR-1-GM (GM-CSF Secreting BC Cell Line) + } \\
\text { Cyclophosphamide + IFN- } \alpha-2 b\end{array}$ & Multiple Targets (Interferon); Tregs & I/II (completed) \\
\hline NCT00622401 & $\mathrm{BC}$ & DC-Tumor Fusion Vaccine + IL-12 & Dendritic Cells; Other (IL-12) & $\mathrm{I} / \mathrm{II}$ (terminated) \\
\hline NCT00317603 & $\mathrm{mBC}$ & Autologous GM-CSF-Secreting BC Cell Vaccine & Dendritic Cells and Other Cells (GM-CSF) & I (active, not recruiting) \\
\hline NCT02427581 & TNBC & $\begin{array}{l}\text { Personalized Synthetic Long Peptide Breast Cancer + } \\
\text { Poly-ICLC }\end{array}$ & TLR & I (recruiting) \\
\hline NCT04024800 & TNBC & $\begin{array}{l}\text { Modified HER2 (AE37) Peptide Vaccine + } \\
\text { Pembrolizumab (Anti-PD-1) }\end{array}$ & Checkpoint Molecules & II (recruiting) \\
\hline NCT00880464 & $\mathrm{BC}$ & Autologous GM-CSF-Secreting BC Cell Vaccine & Dendritic Cells and Other Cells (GM-CSF) & I (active, not recruiting) \\
\hline NCT03199040 & TNBC & Neo-Antigen DNA vaccine + Durvalumab (Anti-PD-1) & Checkpoint Molecules & I (recruiting) \\
\hline NCT03632941 & HER2+ BC & $\begin{array}{l}\text { Neutralized Viral Vector Vaccine (VRP-HER2) + } \\
\text { Pembrolizumab (Anti-PD-1) }\end{array}$ & Checkpoint Molecules & II (recruiting) \\
\hline NCT03384914 & HER2+ BC & $\begin{array}{l}\text { DC1 Vaccine + pUMVC3-IGFBP2-HER2-IGF1R } \\
\text { (WOKVAC) DNA Vaccine }\end{array}$ & Dendritic Cells & II (recruiting) \\
\hline NCT04270149 & $\mathrm{ER}+\mathrm{BC}$ & ESR1 Peptide Vaccine + Montanide + GM-CSF & Dendritic Cells and Other Cells (GM-CSF) & I (not yet recruiting) \\
\hline NCT03387553 & HER2+ & HER2-pulsed DC Vaccine & Dendritic Cells & I (recruiting) \\
\hline NCT04348747 & mTNBC & $\begin{array}{l}\text { Anti-HER2/HER3 DC Vaccine + Celecoxib + } \\
\text { Pembrolizumab (Anti-PD-1) + IFN- } \alpha-2 b\end{array}$ & $\begin{array}{l}\text { Dendritic Cells; Multiple Targets (Interferon); TLR; } \\
\text { Checkpoint Molecules }\end{array}$ & II (not yet recruiting) \\
\hline NCT02780401 & HER2- BC & $\begin{array}{l}\text { pUMVC3-IGFBP2-HER2-IGF1R (WOKVAC) DNA } \\
\text { Vaccine + Sargramostim }\end{array}$ & Dendritic Cells and Other Cells (GM-CSF) & I (active, not recruiting) \\
\hline NCT04105582 & TNBC & Neo-Antigen Pulsed DC Vaccine & Dendritic Cells & I (recruiting) \\
\hline
\end{tabular}


Table 2. Cont

\begin{tabular}{|c|c|c|c|c|}
\hline Clinical Trial ID & BC Type & Vaccine Description & Microenvironment Target & Phase \\
\hline NCT03387085 & TNBC & $\begin{array}{c}\text { Adenoviral and Yeast-based Vaccines (CEA, Brachyury, } \\
\text { MUC1, Mutant RAS) + Bevacizumab (Anti-VEGF) + } \\
\text { Avelumab (Anti-PD-L1) + N-803 (IL-15 Agonist) + } \\
\text { NK-92 (hNK Cells) + Chemotherapy (Varied) + } \\
\text { Radiation }\end{array}$ & $\begin{array}{l}\text { Multi-target (IL-15 agonist); Angiogenesis; Checkpoint } \\
\text { Molecules; NK Cells }\end{array}$ & I/II (active, not recruiting) \\
\hline NCT03606967 & TNBC & $\begin{array}{c}\text { Personalized Synthetic Long Peptide Vaccine + } \\
\text { Nab-paclitaxel + Durvalumab (Anti-PD-1) + Poly-ICLC }\end{array}$ & Checkpoint Molecules; TLR & II (not yet recruiting) \\
\hline NCT03012100 & TNBC & $\begin{array}{l}\text { Folate Receptor Alpha Peptide Vaccine. + Sargramostim } \\
\text { + Cyclophosphamide }\end{array}$ & Dendritic Cells and Other Cells (GM-CSF); Tregs & II (recruiting) \\
\hline NCT03804944 & $\mathrm{ER}+\mathrm{BC}$ & $\begin{array}{l}\text { Flt3L + Radiation Therapy + Pembrolizumab } \\
\text { (Anti-PD-1) }\end{array}$ & $\begin{array}{l}\text { Multi-target (radiation); Checkpoint Molecule; Dendritic } \\
\text { Cells }\end{array}$ & II (active, not recruiting) \\
\hline NCT04197687 & $\mathrm{HER} 2+\mathrm{BC}$ & $\begin{array}{l}\text { HER2 Peptide Vaccine (TPIV100) + Sargramostim + } \\
\text { Pertuzumab + Trastuzumab }\end{array}$ & Dendritic Cells and other cells (GM-CSF) & II (recruiting) \\
\hline NCT04418219 & $\mathrm{BC}$ & $\begin{array}{c}\text { SV-BR-1-GM (GM-CSF Secreting BC Cell Line) + } \\
\text { Cyclophosphamide + IFN- } \alpha-2 b+\text { Pembrolizumab } \\
\text { (Anti-PD-1) }\end{array}$ & $\begin{array}{l}\text { Dendritic Cells and Other Cells (GM-CSF); Multi-target } \\
\text { (Interferon); Checkpoint Molecules }\end{array}$ & I/II (not yet recruiting) \\
\hline NCT04296942 & $\mathrm{mBC}$ & $\begin{array}{l}\text { Brachyury-TRICOM (Vaccinia Viral Vector Based } \\
\text { Brachyury Vaccine) + Entinostat + Adotrastuzumab } \\
\text { Emtansine + M7824 (PD-L1/TGF- } \beta \text { Fusion Protein) }\end{array}$ & Checkpoint Molecules; Myeloid Cells & I (recruiting) \\
\hline NCT01782274 & $\mathrm{mBC}$ & $\begin{array}{l}\text { Proteomic Approach with Allogeneic Haploidentical } \\
\text { Hematopoietic Stem Cells (HSCs) + CTLs + DC Vaccine }\end{array}$ & Multi-target, including Dendritic Cells & $\mathrm{II} / \mathrm{III}$ (enrolling by invite) \\
\hline NCT03789097 & $\mathrm{mBC}$ & $\begin{array}{c}\text { Flt3L + Radiation Therapy + Pembrolizumab } \\
\text { (Anti-PD-1) } \\
+ \text { Poly-ICLC }\end{array}$ & $\begin{array}{c}\text { Multi-target (radiation); Checkpoint Molecules; Dendritic } \\
\text { Cells; TLR }\end{array}$ & I/II (recruiting) \\
\hline NCT00436254 & HER2+ BC & HER2 DNA Vaccine + Sargramostim & Dendritic Cells and Other Cells (GM-CSF) & I (active, not recruiting) \\
\hline NCT04144023 & DCIS & Multi-epitope HER2 Peptide Vaccine + GM-CSF & Dendritic Cells and Other Cells (GM-CSF) & I (recruiting) \\
\hline NCT03564782 & $\mathrm{mBC}$ & PVSRIPO (Oncolytic Poliovirus) & Multi-target (Oncolytic Virus) & I (recruiting) \\
\hline NCT03328026 & $\mathrm{mBC}$ & $\begin{array}{c}\text { SV-BR-1-GM (GM-CSF Secreting BC Cell Line) + } \\
\text { IFN- } \alpha \text {-2b + INCMGA00012 (PD-1 Inhibitor) + } \\
\text { Cyclophosphamide Interferon Inoculation + } \\
\text { Epacadostat (Indoleamine-pyrrole 2,3-dioxygenase-1 } \\
\text { Inhibitor) }\end{array}$ & $\begin{array}{l}\text { Dendritic Cells and Other Cells (GM-CSF); Checkpoint } \\
\text { Molecules; Multi-target (Interferon); Tregs }\end{array}$ & I/II (recruiting) \\
\hline NCT04246671 & HER2+ BC & TAEK-VAC-HerBy Vaccine + PD-1/PD-L1 Inhibition & Checkpoint Molecules & I/II (not yet recruiting) \\
\hline NCT01376505 & HER2+ BC & $\begin{array}{l}\text { HER2 Peptide Vaccine + nor-MDP (Muramyldipeptide } \\
\text { Derivative-a Bacterial Cell wall Peptidoglycan) }\end{array}$ & Multi-target (NOD2 agonist) & I (recruiting) \\
\hline
\end{tabular}


Table 2. Cont.

\begin{tabular}{|c|c|c|c|c|}
\hline Clinical Trial ID & BC Type & Vaccine Description & Microenvironment Target & Phase \\
\hline NCT02491697 & $\mathrm{mBC}$ & $\begin{array}{l}\text { DC-CIK Vaccine (DC Cells Co-cultured with } \\
\text { Cytokine-Induced Killer Cells) + Capecitabine }\end{array}$ & Dendritic Cells & II (active, not recruiting) \\
\hline NCT02432963 & $\mathrm{mBC}$ & $\begin{array}{c}\text { Modified Vaccinia Virus Ankara Vaccine Expressing p53 } \\
+ \text { Pembrolizumab (Anti-PD-1) }\end{array}$ & Checkpoint Molecules & I (active not recruiting) \\
\hline NCT03761914 & TNBC & $\begin{array}{c}\text { Galinpepimut-S. (Wilms Tumor-1-Targeting Multivalent } \\
\text { Heteroclitic Peptide Vaccine) + Pembrolizumab } \\
\text { (Anti-PD-1) }\end{array}$ & Checkpoint Molecules & I/II (recruiting) \\
\hline NCT01997190 & $\mathrm{mBC}$ & $\begin{array}{l}\text { AdV-tk (Adenovirus-mediated Herpes Simplex Virus } \\
\text { Thymidine Kinase Gene Therapy) + Valacyclovir }\end{array}$ & Multi-target (Oncolytic Virus) & I (active not recruiting) \\
\hline NCT03289962 & TNBC & $\begin{array}{l}\text { RO7198457 (Individualized mRNA Vaccine) + } \\
\text { Atezolizumab (Anti-PD-L1) }\end{array}$ & Checkpoint Molecules & I (recruiting) \\
\hline
\end{tabular}




\subsection{Tregs}

CD4+ CD25+ FoxP3+ Treg cells are a major immunosuppressive cell and, while they prevent deleterious autoimmune diseases [50], their presence in the breast cancer TME are a significant hurdle for effective $B C$ vaccine responses [51,52]. Tregs directly suppress leukocytes of the TME and secrete immunosuppressive cytokines such as IL-10. HER2 peptide nelipepimut-S (E75) vaccination strategies for patients with HER2+ cancer may aid in reducing the amount of circulating Tregs [53], highlighting the potential of $\mathrm{BC}$ vaccines to target this immune cell type. Presently, two vaccine adjuvant strategies are being evaluated in clinic to block Treg cells are adjuvant cyclophosphamide [54] (CP; NCT03066947) or Treg blocking antibodies (NCT01660529).

$\mathrm{CP}$ is a commonly used alkylating chemotherapy for patients with $\mathrm{BC}$ and is currently being evaluated as adjuvant for $\mathrm{BC}$ vaccines. Given at routine low doses, $\mathrm{CP}$ significantly impacts Tregs and endothelial cells (antiangiogenic), perhaps by downregulating the TGF- $\beta$ receptor [55] or via ATP-dependent proliferation-dependent cytotoxicity [54]. In patients with advanced breast cancer, metronomic CP administration transiently decreases Tregs while increasing effector CTLs [56]. In a clinical study employing twenty patients with HER2+ BC, an allogenic GM-CSF secreting vaccine with $\mathrm{CP}$ adjuvant increased disease free survival at both seven-month and 42-month timepoints [57]. In this study, Tregs were depleted across all vaccination cycles, including Tregs with CTLA-4 expression. In addition to this study, additional clinical and preclinical studies have tested adjuvant $\mathrm{CP}$ for oncolytic virus therapy, folate receptor peptide vaccines, and other vaccine approaches [58-62].

Two other strategies to suppress TME Tregs in patients with breast cancer are anti-FoxP3 [63] anti-CD25 treatment [64]. Anti-FoxP3 treatment with a neutralizing peptide (p60) in a 4T1 model with DC-based vaccines improved survival outcomes and decreased lung metastasis more than $\mathrm{p} 60$ or vaccine alone [63]. This treatment works via suppressing IL-10 and reducing TME immunosuppression. The other strategy, anti-CD25 treatment (daclizumab), has been interrogated in a clinical trial including patients with metastatic $B C$ receiving an hTERT/survivin based peptide vaccine. The treatment was well tolerated, with statistically significant decline of FoxP3+ CD4 Treg cells at multiple time points. At the two-year point, the majority of patients in the study living with $\mathrm{mBC}$ disease were still alive [64]. Ultimately, $\mathrm{CP}$, anti-FoxP3, and anti-CD25 need to be further explored in human clinical trials as vaccine adjuvants.

\section{Myeloid Cells}

Dendritic cells (DCs) of the TME, sometimes called "natures adjuvants", are crucial in activating CD8+ and CD4+ T-cells by presenting antigens via MHC I and MHC II, respectively [65]. Moreover, they are important costimulatory cells for T-cell activation because they secrete IL-12 and express CD80/86 to bind CD28 on T-cells. However, DCs in the TME are often immature and, instead of activating T-cells, they may suppress them while also promoting tumor growth and angiogenesis $[66,67]$. In cancer models, immature DCs are responsible for facilitating Th2 CD4+ phenotypes, which may facilitate tumor growth [68]. Other immunosuppressive cells in the TME, such as M2 TAMs and MDSCs, as well as signals from tumor cells themselves, such as vascular endothelial growth factor (VEGF), CCL2, and IL-10, are involved in restricting DC maturation. Moreover, CTLA-4 expressed by breast cancer cells may attenuate CD80/86 DC expression and subsequent restricted maturity can hinder proper CD8+ and Th1 CD4+ effector cells [69]. In patients, heavy infiltration of primary breast tumor with CD207+Langerin+ immature DCs are a common pathological feature and, while their presence does not directly affect prognosis in themselves, it is likely they are blunting the immune response to immunotherapies [70,71]. Understanding DC biology in the TME has empowered researchers to modulate DCs in the TME to employ effective vaccine strategies.

There are two ways to mobilize dendritic cells in BC vaccine strategy. First, in the direct DC vaccine strategy, autologous myeloid-lineage cells can be pulsed ex vivo to increase specific antigen presenting capabilities and then reinfused into the patient. Secondly, adjuvants that stimulate DCs in vivo can be used to stimulate maturity, such GM-CSF (granulocyte-macrophage colony-stimulating 
factor), CD40 agonists, TLR agonists, or lentiviral administration of antigens [72] with or without the use of DC vaccines. Thus, both ex vivo and in vivo strategies are sometimes used in tandem.

\subsection{Vaccines}

The goal of effective DC vaccine strategies is to create a proinflammatory TME with effective tumor-specific antigen presentation characteristic of mature DCs. In this process, naïve mononuclear cells or immature DC cells are collected from patients and "pulsed" with TSA/TAA antigens [73,74] or autologous cancer cells [75] to prime activation and antigen presentation before re-injection as a vaccine. Sometimes, the DCs are fused to BC cells in vaccine production [76,77]. Moreover, adjuvants such as IL-12, IFN- $\gamma$, lipopolysaccharides (LPS), and other cocktails are used to induce a mature DC phenotype [78-82]. These pulsed and primed DCs are then inoculated back into the patient or animal model as a vaccine. Recent discoveries have improved the effectiveness of DCs as pro-inflammatory APCs, thereby creating an effective pro-inflammatory TME response. For instance, recent experiments show that microRNAs can further improve maturation and efficacy of dendritic based vaccines, either employing them directly on DCs or tumor-derived exosomes (TEX) interacting with DCs [83-85]. Another effective strategy employs Th1 cytokines, which can increase the efficiency of DC vaccines [86,87]. This rationale is based on successful DC vaccine or DC-targeting vaccine strategies that not only activate effector CD8+ T-cells, but also elicit a Th1 CD4+ proinflammatory response [88,89].

In a clinical trial with patients with ER-PR-double negative $B C$, a DC vaccine was primed with autologous tumor cells before four intradermal injections with no significant reported adverse events [90]. While overall survival was not affected comparing vaccinated and non-vaccinated participants, the progression free survival over three years was significantly improved in patients receiving the DC vaccine. The vaccinated patients had Th- 1 mediated response in addition to increased peripheral CD8+ T-cells and NK cells. Currently, there are DC vaccine strategies employed for clinical trials incorporating priming from HER2, MUC1, autologous cancer cells, and personalized neoantigens, many of which have proven to be safe and effective (see Table 2) [81,82,91-93].

\subsection{DC-Targeting In Situ Vaccination}

In vivo modulation of TME (referred sometimes as in situ vaccination [13]) affects anti-tumor utility of DCs with or without use of ex vivo vaccination strategies. Combining tumor-DC fusion vaccines with IL-12, an in situ DC stimulator, increases vaccine effectiveness in preclinical trials using MCF-7 BC cells [94] and has been tested in a clinical trial involving BC patients (NCT00622401). However, this trial was terminated due to vaccine related toxicities. In a novel in situ strategy, another group of investigators achieved robust anti-tumor response in the $4 \mathrm{~T} 1$ breast cancer model by pulsing dendritic cells with tumor-cell derived exosomes that were fused with the DAMP, nucleosome-binding protein 1 (HMGN1; TEX-N1ND) [95]. This strategy works by exposing DCs to multiple tumor antigens while simultaneously exposing DCs to signs of infection. With TEX-N1ND treatment, tumor-infiltrating CD8+ CTLs and peripheral blood CD8+ T-cells significantly expanded. In addition, there were marked increases in costimulatory molecules (CD83/86; MHC I/II) along with IFN- $\gamma$ and IL-2 cytokines. These novel approaches present new paradigms in which to test existing cancer vaccines.

In similar fashion to DAMP-rich exosomes, TLR agonists can be used alongside DC vaccines to activate pro-inflammatory TME by introducing a PAMP (see NCT03789097). TLR8 agonism increases IL-12 and TNF $\alpha$ secretion via DCs using the small molecule, VTX-2337, while also sensitizing patient BC samples to Rituximab-dependent-cell mediated toxicity [96]. Poly-ICLC (Hiltonol) is a TLR3 agonist comprised of synthetic dsRNA, which stimulates the production of pro-inflammatory cytokines and IFN- $\gamma$ [97-100]; however, there are mixed results regarding TLR3's role in tumor cell intrinsic phenotypes [101,102]. Poly-ICLC is currently being used as an adjuvant to an in-situ vaccine strategy for advanced BC that also includes pembrolizumab, radiation, and FMS-like tyrosine kinase 3 ligand (Flt3L), which primes DCs for maturation and antigen recognition (NCT03789097). Flt3L binds a receptor tyrosine kinase in the TME. This study being led by Brody and colleagues has shown that this vaccine strategy 
induces successful antigen cross-presentation in TLR3+ DCs of tumor microenvironment and subsequent tumor regression in a clinical trial of indolent non-Hodgkin's lymphoma [103]. Upon activation, mature DCs expand and secret proinflammatory cytokines. This work is congruent a with recent study showing E0771 BC cells respond well to adoptive T-cell therapy, with T-cells expressing Ftl3L, combined with Poly-ICLC [104]. Future and ongoing trials will evaluate the translational potential of these in situ vaccination approaches targeting DC cells with and without the use of ex vivo pulsed DC vaccines.

GM-CSF, while having multiple effects across different immune cell types, is a growth factor with strong positive influences on DC recruitment and maturation. It has been used safely by itself or as a BC vaccine adjuvant in many clinical trials, with varying success [57,105-111]. In fact, combination of GM-CSF with Flt3L may further increase peripheral DC counts in patients [112]. In one study, a triple therapy of GM-CSF autologous BC vaccine, trastuzumab, and cyclophosphamide for HER2+ BC conferred a 6-month clinical benefit rate of 55\% [57], which was hypothesized to work via a DC-driven augmentation of CD8+ CTLs [113]. Using a metastatic BC cell line overexpressing GM-CSF (SV-BR-1-GM), BriaCell Therapeutics demonstrated that these cell lines can present not only TAAs, but also MHC I/II molecules and directly act as APCs [114]. In a preclinical study with a Balb/c 4T1 orthoptic BC model, a GM-CSF-based vaccine strategy significantly decreases tumor growth and increases overall survival [115]. Currently, GM-CSF, administered or overexpressed transgenically within tumor, is being evaluated as an adjuvant in clinical trials with HER2 peptide BC/DCIS vaccines (NCT00791037, NCT02636582, NCT02276300, NCT02297698, NCT00524277), folate receptor alpha peptide BC vaccines (NCT02593227, NCT03012100), folate binding peptide BC vaccines (NCT02019524), autologous BC vaccines (NCT00317603, NCT00880464), estrogen receptor peptide BC vaccines (NCT04270149), DNA-based BC vaccines (NCT02790401, NCT00436254), and others.

Immune checkpoint blockers may modulate the TME via DC-driven mechanisms as part of another in situ-based vaccination strategy. DC vaccines in combination with checkpoint inhibitors result in robust immune responses $[46,116]$. Pembrolizumab is currently being tested as an adjuvant in ongoing DC vaccine clinical trial in the setting of TNBC brain metastasis (NCT04348747). In addition to PD-1/PD-L1 inhibition, other checkpoint inhibition strategies appear to work via DCs and may offer novel avenues of DC vaccine adjuvants. Checkpoint inhibition with an anti-T cell Immunoglobulin and Mucin Domain-containing Protein 3 (TIM3) antibody, for instance, suppresses tumor growth via CD103+ DCs. When this antibody was administered alongside nab-paclitaxel in a MMTV-PyMT BC model, dendritic cells activated CD8+ CTL responses via CXCL9 [117]. Therefore, checkpoints inhibitors along with DC activation via vaccines may be an attractive therapeutic route.

Lastly, already established BC treatments also rely heavily on DCs. Immunogenic doses of radiation targeting breast cancer cells, for instance, release breast cancer dsDNA in exosomes, which cause STING-mediated IFN-type-1 activation in DCs of TME [118]. Interestingly, in addition to nurturing mature DCs, radiation therapy may also increase endothelial activation, which recruits leukocytes via upregulation of adhesion proteins [119]. Radiation, poly-ICLC, and DC vaccine triple therapy has been tested in a phase I trial for advance cancer, including BC, and appears to be safe and immunostimulatory [120]. In addition to radiation therapy, other common BC therapies such as trastuzumab increase soluble HER2/neu uptake and presentation by DCs in HER2+ models of BC [121]. Meanwhile, nab-paclitaxel in combination with DC injection increase anti-tumor responses in a DA3 cancer model [122]. While these established therapies have been traditionally viewed as immunosuppressive because they are cytotoxic, the recent literature has opened up new avenues of TME exploitation that mat benefit immunotherapy efficacy. These preclinical studies that interrogate the microenvironment may help guide future clinical trial design with DC vaccines or other BC vaccine strategies.

\subsection{MDSCs}

Myeloid derived suppressor cells (MDSCs), another major component in the TME, suppress TILs, promote tumor angiogenesis, and support tumor growth $[123,124]$. For instance, CXL2/CCL2 from 
TNBC cells recruit MDSCs, which then promote stem cell phenotypes and metastatic behavior in TNBCs via chitinase-3-like protein-1 and matrix metallopeptidase-9 [125].

MDSC targeting adjuvants could potentially be used as vaccine adjuvants. For example, poly-ICLC (TLR3 agonist; vaccine adjuvant discussed vide supra) decreases tumor and peripheral MDSCs [126]. The presence of MDSCs can also be reduced with entinostat (a HDAC inhibitor) in conjunction with checkpoint inhibitors [127]. Doxorubicin pretreatment, followed by FAP/survivin DNA vaccine, reduces 4T1 TNBC cell growth by eliminating MDSCs [128]. These observations are consistent with other in situ, B-cell based, and other vaccine strategies that eliminate MDSCS [129-131]. Additional work is required to interrogate the role of MDSCs in vaccine success and test MDSC-targeting adjuvants in $\mathrm{BC}$ vaccine clinical trials.

\section{Oncolytic Viruses}

Oncolytic viruses (OV) transform immunotherapy from a sterile immunity to a pathogen-associatedlike immunity, as these viruses replicate preferentially in tumor cells and release TAAs and PAMPS [132,133]. In this emerging in situ vaccination strategy in breast cancer models, pox- [134,135], reo- [136], herpes simplex [137-139], adeno- [140-143], Newcastle disease [144,145], Vesicular stomatitis [146], and measles [147-149] viruses have been employed to make breast tumors more immunogenic and more responsive to immunotherapies by priming the TME to signs of infection and releasing TAAs [150]. Moreover, these viruses can be engineered to express various TAAs to further prime an immunological response from TME. In the last couple years, the field of oncolytic viruses in BC models has been burgeoning and opened new avenues for combination immunotherapies, such as vaccines [146,151], suppressor cell targeting [152], and checkpoint inhibitors [134,140,146,150,152-156]. Moreover, several BC clinical trials are currently ongoing (see Table 2).

\subsection{In Situ TME Changes with Oncolytic Viruses}

OVs have been appreciated for many years for their preferential affinity for malignant-cells [148], but the recent explosion in immunotherapies, virology, and molecular genetics have truly opened up new potential to combine OVs with checkpoint inhibitors, adoptive $\mathrm{T}$ transfer, and $\mathrm{BC}$ vaccines [132]. In 2015, the Food and Drug Administration (FDA) approved the first OV therapy-a GM-CSF-based HSV1-for unresectable melanoma [157]. Researchers have leveraged the cancer cell's compromised innate immune system, such as faulty TLRs, IFNs, and protein kinase- R (PKR) pathways, which allows a viral infection in the TME that spares normal cells [132]. New technologies have primed OVs to become more specific and effective in targeting tumor cells and lysing them in the process, including arming them with pro-apoptotic signaling molecules [147]. Importantly, the lysing of tumor cells releases TAAs and DAMPs from the cancer cells and PAMPs from the virus particles. Recently, numerous periclinal $\mathrm{BC}$ experiments have demonstrated promising results with clinical trial candidates, many of which have entered phase I/II clinical trials [133,143] (see Table 2).

There are currently many creative applications of OVs in recent years, which show very promising results in preclinical BC models. Some of the strategies in breast cancer engineer the viruses to express immune stimulatory molecules or cytokines, such as IL-2 [152], IL-12 [137,144], and GM-CSF [153]. In other instances, researchers have engineered viral-like nanoparticles with immune stimulatory molecules such as IL-33 [158]. Recently, a group of investigators engineered an oncolytic adenovirus expressing a TGF- $\beta$ decoy (sTGF $\beta$ RIIFc), which inhibited pro-tumorigenic signaling from fibroblasts in the TME of TNBC models [140]. This strategy was combined with checkpoint inhibitors in a 4T1 $\mathrm{Balb} / \mathrm{c}$ model, which led to significant tumor regression. In a similar strategy, Zhao et al. expressed decorin, a TGF- $\beta$ inhibitor, in an oncolytic adenovirus, which significantly reduced lung metastasis in a 4T1 Balb/c model when injected intravenously [142]. While interrogating a mechanism of decreased lung metastasis, they demonstrated CD8+ T-cell augmentation and a CD4+ Th1 bias in the lung with the presence of IL-2, IL-12, and TNF $\alpha$, with a corresponding decrease in Th2 cytokines and angiogenic signals such as VEGF. In yet another strategy, an interferon small molecule inhibitor led 
to increased intratumor oncolytic herpes simplex replication, which increased the infiltration of M1 polarized macrophages in the TME of a TNBC xenograft model. Other research groups have expressed CD40ligands in adeno-OV with similarly successful results [159]. Therefore, the in-situ changes with the use of OVs primes the TME for inflammation, opening the door to enhance antigen presentation and attack via CD8 T-cell-inducing vaccines [132].

\subsection{Oncolytic Viruses Combined with Peptide Vaccines}

Niavarani, et al. have recently employed an autologous $4 \mathrm{~T} 1$ cell vaccine (inactivated by gammairradiation) infected with Recombinant Vesicular Stomatitis Virus (VSVd51) [146]. The vaccine was injected subcutaneously in TNBC models using MDA-MB-231, BT-549, and 4T1 TNBC cell lines. VSVd51 is a rhabdovirus engineered to preferentially infect cancer cells via a point mutation in gene encoding its matrix M protein. Cancer cells are preferentially targeted by VSVd51 because they are unable to mount a proper IFN response, whereas normal cells can. Upon administration of VSVd51, the tumors become necrotic with intratumoral expression of pro-inflammatory gene signatures including MHC I, CCL5, and CXCL10 in all three TNBC models. In the 4T1 model, IFN- $\gamma$, IL-2, and PD-1 were also upregulated. In the 4T1 model, there was marked increase of multiple NK cell subtypes, CD11c+ CD86+ DCs, and effector CD8+ CTLs in infection-vaccine combination compared to either VSVd51 or vaccine alone. In fact, anti-tumor results in the combination treatment group were dependent on CD8+ $\mathrm{T}$-cell infiltration as their removal abrogated the vaccine-OV response.

Of interest, based on observation of CD8+ T-cell infiltration, Niavarani et al. combined their vaccine-OV approach with anti-PD-1 treatment, which improved overall survival compared to PD-1 or vaccine-OV alone in a 4T1-Balb/c model [146]. This might be an indication of a wider trend in BC-OV research, as multiple groups have seen $\mathrm{BC}$ tumor regression and increased survival by combining OVs with checkpoint inhibitors [134,140,146,150,152-156]. Chon et al., for instance, used antibodies blocking both CTLA-4 and PD-1 in a MMTV-PyMT transgenic mouse model administration of mJX-594 (JX), a vaccinia virus engineered to express GM-CSF and is attenuated via viral thymidine kinase disruption [153]. JX combined with anti-CTLA-4 and anti-PD-1 significantly decreased tumor burden and lung metastasis while increasing overall survival compared to any other group. Remarkably, the triple therapy impacted the TME to a pro-inflammatory state, with evident increase of CD8+ T-cell infiltration. In the same study, the investigators saw decreased CD31+ (tumor angiogenesis), with marked increase of CD8+ cytotoxic T-cells, CD11c+ DCs, and PD-L1+ in the TME of a Renca Balb/c model, showcasing even more drastic TME changes than a MMTV-PyMT orthotopic model. Future studies can continue to interrogate TME immune and vascular cells, while testing OV, vaccine, and checkpoint inhibitor combination therapy. In fact, a reo-OV (Pelareorep) is currently being tested in combination with anti-PD-L1 (avelumab) and nab-paclitaxel for patients with ER+HER2- metastatic breast cancer (NCT04215146).

\section{Microenvironment Antigen Vaccines}

\subsection{Tumor Endothelia}

Vascular cells in the TME affect tumors in multiple ways: (1) blood supply to the tumor, (2) infiltration of CTLs via endothelial adhesion proteins, similar to inflammatory processes [21,160], and (3) the intravasation and extravasation of circulating tumor cells (CTC) during the metastatic process, similar to the leukocyte extravasation pathways [161,162]. Pathological angiogenesis in the vascular TME can suppress effective immunotherapies, which can potentially be overcome by antiangiogenesis strategies that "normalize" the endothelium [163]. Antiangiogenic anti-VEGF therapy targeting via bevacizumab (Avastin) lost its indication status for BC in 2011 from the FDA, but its use remains controversial as it is relatively safe and confers minor benefits for select patients [164]. Anti-VEGF therapy is prone to resistance and adverse events (due to hypoxia-induced pro-metastatic phenotypes) across many cancers [165]. Researchers have resorted to alternative angiogenesis targeting methods in preclinical 
studies. For instance, targeting Notch ligands with decoys that utilize the EGF-like repeats of the Notch1 receptor decrease tumor growth and angiogenesis in orthotopic breast cancer models with minimal adverse events [166]. Moreover, angiogenesis is an emerging target for BC vaccine strategies, mostly in the preclinical phase. In the clinic, a recently completed phase I DC vaccine strategy pulsed DC cells with tumor blood vessel antigens (TBVA) (NCT02479230).

Yu-Quan Wei was the first to pioneer "endothelial cell vaccines" around twenty years ago [167] and, since then, multiple strategies have been tested in preclinical models of BC [168]. There are several endothelial vaccine strategies that have been tested, including whole-cell endothelial-based $[169,170]$, TBVA-targeting [171], EGFR-targeting [172,173], CD105-targeting [174,175], PDGFR- $\beta$-targeting [176], and VEGF targeting $[169,173,177-180]$ vaccines. Not only do the vaccines attack tumor growth by directing immune responses against tumor angiogenesis, but the inflammatory consequences of the immune attack lead to increased CD8+ CTLs infiltrating into the TME $[167,170]$. In one of the studies, a mutant VEGF (VEGF165b) was used alongside MUC1 in a peptide vaccine strategy in a EMT-6 Balb/c BC model [180]. The strategy increased antibody titers to wildtype VEGF 200,000-fold while reducing Tregs and increasing MUC1-specific CD8 T-cells. Moreover, the authors showed an ability of vaccine mediated anti-VEGF antibodies taken from serum to inhibit endothelial cells from proliferating in vitro. This study is an example in which both tumor antigen presentation and pro-inflammatory TME elements are increased by combining TAA and TME antigen vaccination strategies.

Recent transcriptional analysis of the endothelium in homeostasis and disease states has revealed striking heterogeneity depending on vascular bed or disease context [181,182]. Further understanding of the tumor vasculature may increase our ability to target tumor endothelial antigens in vaccination strategies with or without TME-stimulating adjuvants.

\section{2. $C A F s$}

Cancer associated fibroblasts (CAFs) of the TME are transcriptionally, genetically, and epigenetically unique compared to the surrounding fibroblasts of normal tissue, with notable upregulation of Notch2 and genome-wide methylation signatures [183-185]. CAFs promote pro-tumorigenic and metastatic phenotypes, as demonstrated by xenograft modelling [186] and single cell analysis of immune-resistant cancer cell populations [184].

There are two main CAF-vaccine strategies. First, CAF-associated antigens have been targeted by DNA and recombinant peptide vaccines [128,187-190]. Two of these vaccines, for instance, targeted fibroblast activation protein-alpha (FAP- $\alpha$ ) using DNA-based vaccines in 4T1 mouse models [187-189]. Targeting of FAPa led to a decrease in CAFs present, which resulted in decreased CCL2/CXCL12 expression and MDSC presence. This resulted in increased anti-tumor response and overall survival. The other CAF-related strategy employs allogenic fibroblasts transfected to express TAAs to promote immune response [191,192]. Essentially, immune-stimulatory CAFs are engineered to present tumor antigens and initiate a pro-inflammatory anti-tumorigenic environment. It has yet to be seen whether these preclinical studies will be translated in a meaningful way to help patients.

\section{Summary and Future Directions}

The immune system has evolved over the course of millions of years primarily in an arms race against pathogens. Anti-cancer immunity, however, poses a more delicate balance as the immune system must navigate a complicated terrain of "self" versus "non-self" in which autoimmune pathology is at odds with cancer immunosurveillance. At the heart of this balance is the TME, which is instrumental not only in supporting an oncogenic niche, but also in deciding whether or not the immune cells of the local environment will become active once they recognize immunogenic properties of the tumor. Therefore, while $B C$ vaccines can help with antigen presentation, the rate limiting step may be outside the realm of TSAs and TAAs. Instead, it may be within the TME. Multiple TME-targeting vaccine-based clinical trials (see Table 2 ) are underway for patients with various $B C$ subtypes. While checkpoint inhibitors for cases of TNBC are leading the forefront of $\mathrm{BC}$ immunotherapies, $\mathrm{BC}$ vaccine 
strategies are now also targeting or utilizing immunostimulatory molecules, immunosuppressive cells, and other components of the TME in order to develop effective therapeutic BC vaccines as part of combination strategies.

Author Contributions: B.G. and V.K.G. performed the literature review and prepared the manuscript. All authors have read and agreed to the published version of the manuscript.

Funding: B.G. is supported by NIH grant 5T32HL144459-02.

Conflicts of Interest: The authors declare no conflict of interest.

\section{References}

1. Hodi, F.S.; O’Day, S.J.; McDermott, D.F.; Weber, R.W.; Sosman, J.A.; Haanen, J.B.; Gonzalez, R.; Robert, C.; Schadendorf, D.; Hassel, J.C.; et al. Improved survival with ipilimumab in patients with metastatic melanoma. N. Engl. J. Med. 2010, 363, 711-723. [CrossRef]

2. Robert, C.; Thomas, L.; Bondarenko, I.; O’Day, S.; Weber, J.; Garbe, C.; Lebbe, C.; Baurain, J.F.; Testori, A.; Grob, J.J.; et al. Ipilimumab plus dacarbazine for previously untreated metastatic melanoma. N. Engl. J. Med. 2011, 364, 2517-2526. [CrossRef] [PubMed]

3. Borghaei, H.; Paz-Ares, L.; Horn, L.; Spigel, D.R.; Steins, M.; Ready, N.E.; Chow, L.Q.; Vokes, E.E.; Felip, E.; Holgado, E.; et al. Nivolumab versus Docetaxel in Advanced Nonsquamous Non-Small-Cell Lung Cancer. N. Engl. J. Med. 2015, 373, 1627-1639. [CrossRef] [PubMed]

4. Garon, E.B.; Rizvi, N.A.; Hui, R.; Leighl, N.; Balmanoukian, A.S.; Eder, J.P.; Patnaik, A.; Aggarwal, C.; Gubens, M.; Horn, L.; et al. Pembrolizumab for the treatment of non-small-cell lung cancer. N. Engl. J. Med. 2015, 372, 2018-2028. [CrossRef] [PubMed]

5. Larkin, J.; Chiarion-Sileni, V.; Gonzalez, R.; Grob, J.J.; Cowey, C.L.; Lao, C.D.; Schadendorf, D.; Dummer, R.; Smylie, M.; Rutkowski, P.; et al. Combined Nivolumab and Ipilimumab or Monotherapy in Untreated Melanoma. N. Engl. J. Med. 2015, 373, 23-34. [CrossRef] [PubMed]

6. Gibney, G.T.; Weiner, L.M.; Atkins, M.B. Predictive biomarkers for checkpoint inhibitor-based immunotherapy. Lancet Oncol. 2016, 17, e542-e551. [CrossRef]

7. Darvin, P.; Toor, S.M.; Sasidharan Nair, V.; Elkord, E. Immune checkpoint inhibitors: Recent progress and potential biomarkers. Exp. Mol. Med. 2018, 50, 1-11. [CrossRef]

8. Garcia-Aranda, M.; Redondo, M. Immunotherapy: A Challenge of Breast Cancer Treatment. Cancers 2019, 11, 1822. [CrossRef]

9. Schlom, J.; Hodge, J.W.; Palena, C.; Tsang, K.Y.; Jochems, C.; Greiner, J.W.; Farsaci, B.; Madan, R.A.; Heery, C.R.; Gulley, J.L. Therapeutic cancer vaccines. Adv. Cancer Res. 2014, 121, 67-124. [CrossRef]

10. Tower, H.; Ruppert, M.; Britt, K. The Immune Microenvironment of Breast Cancer Progression. Cancers 2019, 11, 1375. [CrossRef]

11. Lei, X.; Lei, Y.; Li, J.K.; Du, W.X.; Li, R.G.; Yang, J.; Li, J.; Li, F.; Tan, H.B. Immune cells within the tumor microenvironment: Biological functions and roles in cancer immunotherapy. Cancer Lett. 2020, 470, 126-133. [CrossRef] [PubMed]

12. Bhat, V.; Allan, A.L.; Raouf, A. Role of the Microenvironment in Regulating Normal and Cancer Stem Cell Activity: Implications for Breast Cancer Progression and Therapy Response. Cancers 2019, 11, 1240. [CrossRef] [PubMed]

13. Locy, H.; de Mey, S.; de Mey, W.; De Ridder, M.; Thielemans, K.; Maenhout, S.K. Immunomodulation of the Tumor Microenvironment: Turn Foe Into Friend. Front. Immunol. 2018, 9, 2909. [CrossRef] [PubMed]

14. Predina, J.; Eruslanov, E.; Judy, B.; Kapoor, V.; Cheng, G.; Wang, L.C.; Sun, J.; Moon, E.K.; Fridlender, Z.G.; Albelda, S.; et al. Changes in the local tumor microenvironment in recurrent cancers may explain the failure of vaccines after surgery. Proc. Natl. Acad. Sci. USA 2013, 110, E415-E424. [CrossRef] [PubMed]

15. Allahverdiyev, A.; Tari, G.; Bagirova, M.; Abamor, E.S. Current Approaches in Development of Immunotherapeutic Vaccines for Breast Cancer. J. Breast Cancer 2018, 21, 343-353. [CrossRef] [PubMed]

16. Li, X.; Bu, X. Progress in Vaccine Therapies for Breast Cancer. Adv. Exp. Med. Biol. 2017, 1026, 315-330. [CrossRef]

17. Ren, Y.; Cherukuri, Y.; Wickland, D.P.; Sarangi, V.; Tian, S.; Carter, J.M.; Mansfield, A.S.; Block, M.S.; Sherman, M.E.; Knutson, K.L.; et al. HLA class-I and class-II restricted neoantigen loads predict overall survival in breast cancer. Oncoimmunology 2020, 9. [CrossRef] 
18. Costa, R.; Zaman, S.; Sharpe, S.; Helenowski, I.; Shaw, C.; Han, H.; Soliman, H.; Czerniecki, B. A brief report of toxicity end points of HER2 vaccines for the treatment of patients with HER2(+) breast cancer. Drug Des. Devel. Ther. 2019, 13, 309-316. [CrossRef]

19. Soysal, S.D.; Tzankov, A.; Muenst, S.E. Role of the Tumor Microenvironment in Breast Cancer. Pathobiology 2015, 82, 142-152. [CrossRef]

20. Amendola, P.G.; Reuten, R.; Erler, J.T. Interplay Between LOX Enzymes and Integrins in the Tumor Microenvironment. Cancers 2019, 11, 729. [CrossRef]

21. Muller, W.A. Localized signals that regulate transendothelial migration. Curr. Opin. Immunol. 2016, 38, 24-29. [CrossRef] [PubMed]

22. Ali, H.R.; Provenzano, E.; Dawson, S.J.; Blows, F.M.; Liu, B.; Shah, M.; Earl, H.M.; Poole, C.J.; Hiller, L.; Dunn, J.A.; et al. Association between CD8+ T-cell infiltration and breast cancer survival in 12,439 patients. Ann. Oncol. 2014, 25, 1536-1543. [CrossRef]

23. Stanton, S.E.; Disis, M.L. Clinical significance of tumor-infiltrating lymphocytes in breast cancer. J. Immunother. Cancer 2016, 4, 59. [CrossRef]

24. Denkert, C.; Loibl, S.; Noske, A.; Roller, M.; Muller, B.M.; Komor, M.; Budczies, J.; Darb-Esfahani, S.; Kronenwett, R.; Hanusch, C.; et al. Tumor-associated lymphocytes as an independent predictor of response to neoadjuvant chemotherapy in breast cancer. J. Clin. Oncol. 2010, 28, 105-113. [CrossRef]

25. Canale, F.P.; Ramello, M.C.; Nunez, N.; Araujo Furlan, C.L.; Bossio, S.N.; Gorosito Serran, M.; Tosello Boari, J.; Del Castillo, A.; Ledesma, M.; Sedlik, C.; et al. CD39 Expression Defines Cell Exhaustion in Tumor-Infiltrating CD8(+) T Cells. Cancer Res. 2018, 78, 115-128. [CrossRef]

26. Savas, P.; Virassamy, B.; Ye, C.; Salim, A.; Mintoff, C.P.; Caramia, F.; Salgado, R.; Byrne, D.J.; Teo, Z.L.; Dushyanthen, S.; et al. Single-cell profiling of breast cancer T cells reveals a tissue-resident memory subset associated with improved prognosis. Nat. Med. 2018, 24, 986-993. [CrossRef]

27. Chung, W.; Eum, H.H.; Lee, H.O.; Lee, K.M.; Lee, H.B.; Kim, K.T.; Ryu, H.S.; Kim, S.; Lee, J.E.; Park, Y.H.; et al. Single-cell RNA-seq enables comprehensive tumour and immune cell profiling in primary breast cancer. Nat. Commun. 2017, 8. [CrossRef] [PubMed]

28. Jiang, Y.; Li, Y.; Zhu, B. T-cell exhaustion in the tumor microenvironment. Cell Death Dis. 2015, 6, e1792. [CrossRef] [PubMed]

29. Schmid, P.; Adams, S.; Rugo, H.S.; Schneeweiss, A.; Barrios, C.H.; Iwata, H.; Dieras, V.; Hegg, R.; Im, S.A.; Shaw Wright, G.; et al. Atezolizumab and Nab-Paclitaxel in Advanced Triple-Negative Breast Cancer. N. Engl. J. Med. 2018, 379, 2108-2121. [CrossRef]

30. Ren, X.; Wu, H.; Lu, J.; Zhang, Y.; Luo, Y.; Xu, Q.; Shen, S.; Liang, Z. PD1 protein expression in tumor infiltrated lymphocytes rather than PDL1 in tumor cells predicts survival in triple-negative breast cancer. Cancer Biol. Ther. 2018, 19, 373-380. [CrossRef]

31. Huang, W.; Ran, R.; Shao, B.; Li, H. Prognostic and clinicopathological value of PD-L1 expression in primary breast cancer: A meta-analysis. Breast Cancer Res. Treat. 2019, 178, 17-33. [CrossRef] [PubMed]

32. Le, D.T.; Durham, J.N.; Smith, K.N.; Wang, H.; Bartlett, B.R.; Aulakh, L.K.; Lu, S.; Kemberling, H.; Wilt, C.; Luber, B.S.; et al. Mismatch repair deficiency predicts response of solid tumors to PD-1 blockade. Science 2017, 357, 409-413. [CrossRef] [PubMed]

33. Marabelle, A.; Le, D.T.; Ascierto, P.A.; Di Giacomo, A.M.; De Jesus-Acosta, A.; Delord, J.P.; Geva, R.; Gottfried, M.; Penel, N.; Hansen, A.R.; et al. Efficacy of Pembrolizumab in Patients With Noncolorectal High Microsatellite Instability/Mismatch Repair-Deficient Cancer: Results From the Phase II KEYNOTE-158 Study. J. Clin. Oncol. 2020, 38, 1-10. [CrossRef]

34. Anbazhagan, R.; Fujii, H.; Gabrielson, E. Microsatellite instability is uncommon in breast cancer. Clin. Cancer Res. 1999, 5, 839-844.

35. Ravaioli, S.; Limarzi, F.; Tumedei, M.M.; Palleschi, M.; Maltoni, R.; Bravaccini, S. Are we ready to use TMB in breast cancer clinical practice? Cancer Immunol. Immunother. 2020. [CrossRef]

36. Barroso-Sousa, R.; Keenan, T.E.; Pernas, S.; Exman, P.; Jain, E.; Garrido-Castro, A.C.; Hughes, M.; Bychkovsky, B.; Umeton, R.; Files, J.L.; et al. Tumor Mutational Burden and PTEN Alterations as Molecular Correlates of Response to PD-1/L1 Blockade in Metastatic Triple-Negative Breast Cancer. Clin. Cancer Res. 2020, 26, 2565-2572. [CrossRef] [PubMed]

37. Mei, P.; Freitag, C.E.; Wei, L.; Zhang, Y.; Parwani, A.V.; Li, Z. High tumor mutation burden is associated with DNA damage repair gene mutation in breast carcinomas. Diagn. Pathol. 2020, 15, 50. [CrossRef] 
38. Hollern, D.P.; Xu, N.; Thennavan, A.; Glodowski, C.; Garcia-Recio, S.; Mott, K.R.; He, X.; Garay, J.P.; Carey-Ewend, K.; Marron, D.; et al. B Cells and T Follicular Helper Cells Mediate Response to Checkpoint Inhibitors in High Mutation Burden Mouse Models of Breast Cancer. Cell 2019, 179, 1191-1206.e1121. [CrossRef]

39. Chung, V.; Kos, F.J.; Hardwick, N.; Yuan, Y.; Chao, J.; Li, D.; Waisman, J.; Li, M.; Zurcher, K.; Frankel, P.; et al. Evaluation of safety and efficacy of p53MVA vaccine combined with pembrolizumab in patients with advanced solid cancers. Clin. Transl. Oncol. 2019, 21, 363-372. [CrossRef]

40. Knudson, K.M.; Hicks, K.C.; Luo, X.; Chen, J.Q.; Schlom, J.; Gameiro, S.R. M7824, a novel bifunctional anti-PD-L1/TGFbeta Trap fusion protein, promotes anti-tumor efficacy as monotherapy and in combination with vaccine. Oncoimmunology 2018, 7, e1426519. [CrossRef]

41. Liu, L.; Wang, Y.; Miao, L.; Liu, Q.; Musetti, S.; Li, J.; Huang, L. Combination Immunotherapy of MUC1 mRNA Nano-vaccine and CTLA-4 Blockade Effectively Inhibits Growth of Triple Negative Breast Cancer. Mol. Ther. 2018, 26, 45-55. [CrossRef] [PubMed]

42. Goldoy-Carderon, M.; Gonzalez-Marcano, E.; Carballo, J.; Convit, A.F. Evaluation of a ConvitVax/anti-PD-1 combined immunotherapy for breast cancer treatment. Oncotarget 2019, 10, 6546-6560.

43. Tan, Z.; Chiu, M.S.; Yan, C.W.; Wong, Y.C.; Huang, H.; Man, K.; Chen, Z. Antimesothelioma Immunotherapy by CTLA-4 Blockade Depends on Active PD1-Based TWIST1 Vaccination. Mol. Ther. Oncolytics 2020, 16, 302-317. [CrossRef] [PubMed]

44. Karyampudi, L.; Lamichhane, P.; Scheid, A.D.; Kalli, K.R.; Shreeder, B.; Krempski, J.W.; Behrens, M.D.; Knutson, K.L. Accumulation of memory precursor CD8 T cells in regressing tumors following combination therapy with vaccine and anti-PD-1 antibody. Cancer Res. 2014, 74, 2974-2985. [CrossRef]

45. Chen, Z.; Hu, K.; Feng, L.; Su, R.; Lai, N.; Yang, Z.; Kang, S. Senescent cells re-engineered to express soluble programmed death receptor-1 for inhibiting programmed death receptor-1/programmed death ligand-1 as a vaccination approach against breast cancer. Cancer Sci. 2018, 109, 1753-1763. [CrossRef]

46. Hassannia, H.; Ghasemi Chaleshtari, M.; Atyabi, F.; Nosouhian, M.; Masjedi, A.; Hojjat-Farsangi, M.; Namdar, A.; Azizi, G.; Mohammadi, H.; Ghalamfarsa, G.; et al. Blockage of immune checkpoint molecules increases T-cell priming potential of dendritic cell vaccine. Immunology 2020, 159, 75-87. [CrossRef]

47. Kodumudi, K.N.; Ramamoorthi, G.; Snyder, C.; Basu, A.; Jia, Y.; Awshah, S.; Beyer, A.P.; Wiener, D.; Lam, L.; Zhang, H.; et al. Sequential Anti-PD1 Therapy Following Dendritic Cell Vaccination Improves Survival in a HER2 Mammary Carcinoma Model and Identifies a Critical Role for CD4 T Cells in Mediating the Response. Front. Immunol. 2019, 10, 1939. [CrossRef]

48. Huang, Y.; Ma, C.; Zhang, Q.; Ye, J.; Wang, F.; Zhang, Y.; Hunborg, P.; Varvares, M.A.; Hoft, D.F.; Hsueh, E.C.; et al. CD4 + and CD8 + T cells have opposing roles in breast cancer progression and outcome. Oncotarget 2015, 6, 17462-17478. [CrossRef]

49. Foote, J.B.; Kok, M.; Leatherman, J.M.; Armstrong, T.D.; Marcinkowski, B.C.; Ojalvo, L.S.; Kanne, D.B.; Jaffee, E.M.; Dubensky, T.W., Jr.; Emens, L.A. A STING Agonist Given with OX40 Receptor and PD-L1 Modulators Primes Immunity and Reduces Tumor Growth in Tolerized Mice. Cancer Immunol. Res. 2017, 5, 468-479. [CrossRef]

50. Kim, J.M.; Rasmussen, J.P.; Rudensky, A.Y. Regulatory T cells prevent catastrophic autoimmunity throughout the lifespan of mice. Nat. Immunol. 2007, 8, 191-197. [CrossRef]

51. Arab, A.; Nicastro, J.; Slavcev, R.; Razazan, A.; Barati, N.; Nikpoor, A.R.; Brojeni, A.A.M.; Mosaffa, F.; Badiee, A.; Jaafari, M.R.; et al. Lambda phage nanoparticles displaying HER2-derived E75 peptide induce effective E75-CD8(+) T response. Immunol. Res. 2018, 66, 200-206. [CrossRef] [PubMed]

52. Bates, G.J.; Fox, S.B.; Han, C.; Leek, R.D.; Garcia, J.F.; Harris, A.L.; Banham, A.H. Quantification of regulatory T cells enables the identification of high-risk breast cancer patients and those at risk of late relapse. J. Clin. Oncol. 2006, 24, 5373-5380. [CrossRef] [PubMed]

53. Hueman, M.T.; Stojadinovic, A.; Storrer, C.E.; Foley, R.J.; Gurney, J.M.; Shriver, C.D.; Ponniah, S.; Peoples, G.E. Levels of circulating regulatory CD4+CD25+ T cells are decreased in breast cancer patients after vaccination with a HER2/neu peptide (E75) and GM-CSF vaccine. Breast Cancer Res. Treat. 2006, 98, 17-29. [CrossRef] [PubMed]

54. Madondo, M.T.; Quinn, M.; Plebanski, M. Low dose cyclophosphamide: Mechanisms of T cell modulation. Cancer Treat. Rev. 2016, 42, 3-9. [CrossRef] [PubMed]

55. Zhong, H.; Lai, Y.; Zhang, R.; Daoud, A.; Feng, Q.; Zhou, J.; Shang, J. Low Dose Cyclophosphamide Modulates Tumor Microenvironment by TGF- $\beta$ Signaling Pathway. Int. J. Mol. Sci. 2020, 21, 957. [CrossRef] [PubMed] 
56. Ge, Y.; Domschke, C.; Stoiber, N.; Schott, S.; Heil, J.; Rom, J.; Blumenstein, M.; Thum, J.; Sohn, C.; Schneeweiss, A.; et al. Metronomic cyclophosphamide treatment in metastasized breast cancer patients: Immunological effects and clinical outcome. Cancer Immunol. Immunother. 2012, 61, 353-362. [CrossRef]

57. Chen, G.; Gupta, R.; Petrik, S.; Laiko, M.; Leatherman, J.M.; Asquith, J.M.; Daphtary, M.M.; Garrett-Mayer, E.; Davidson, N.E.; Hirt, K.; et al. A feasibility study of cyclophosphamide, trastuzumab, and an allogeneic GM-CSF-secreting breast tumor vaccine for HER2+ metastatic breast cancer. Cancer Immunol. Res. 2014, 2, 949-961. [CrossRef]

58. Le, D.T.; Jaffee, E.M. Regulatory T-cell modulation using cyclophosphamide in vaccine approaches: A current perspective. Cancer Res. 2012, 72, 3439-3444. [CrossRef]

59. Wang, Q.; Cao, W.; Yang, Z.G.; Zhao, G.F. DC targeting DNA vaccines induce protective and therapeutic antitumor immunity in mice. Int. J. Clin. Exp. Med. 2015, 8, 17565-17577.

60. Kalli, K.R.; Block, M.S.; Kasi, P.M.; Erskine, C.L.; Hobday, T.J.; Dietz, A.; Padley, D.; Gustafson, M.P.; Shreeder, B.; Puglisi-Knutson, D.; et al. Folate Receptor Alpha Peptide Vaccine Generates Immunity in Breast and Ovarian Cancer Patients. Clin. Cancer Res. 2018, 24, 3014-3025. [CrossRef]

61. Cai, H.; Wang, C.; Shukla, S.; Steinmetz, N.F. Cowpea Mosaic Virus Immunotherapy Combined with Cyclophosphamide Reduces Breast Cancer Tumor Burden and Inhibits Lung Metastasis. Adv. Sci. 2019, 6. [CrossRef] [PubMed]

62. Liu, Y.; Tuve, S.; Persson, J.; Beyer, I.; Yumul, R.; Li, Z.Y.; Tragoolpua, K.; Hellström, K.E.; Roffler, S.; Lieber, A. Adenovirus-mediated intratumoral expression of immunostimulatory proteins in combination with systemic Treg inactivation induces tumor-destructive immune responses in mouse models. Cancer Gene Ther. 2011, 18, 407-418. [CrossRef] [PubMed]

63. Moreno Ayala, M.A.; Gottardo, M.F.; Imsen, M.; Asad, A.S.; Bal de Kier Joffé, E.; Casares, N.; Lasarte, J.J.; Seilicovich, A.; Candolfi, M. Therapeutic blockade of Foxp3 in experimental breast cancer models. Breast Cancer Res. Treat. 2017, 166, 393-405. [CrossRef] [PubMed]

64. Rech, A.J.; Mick, R.; Martin, S.; Recio, A.; Aqui, N.A.; Powell, D.J., Jr.; Colligon, T.A.; Trosko, J.A.; Leinbach, L.I.; Pletcher, C.H.; et al. CD25 blockade depletes and selectively reprograms regulatory T cells in concert with immunotherapy in cancer patients. Sci. Transl. Med. 2012, 4, 134ra162. [CrossRef] [PubMed]

65. Benencia, F.; Sprague, L.; McGinty, J.; Pate, M.; Muccioli, M. Dendritic cells the tumor microenvironment and the challenges for an effective antitumor vaccination. J. Biomed. Biotechnol. 2012, 2012. [CrossRef]

66. Fainaru, O.; Almog, N.; Yung, C.W.; Nakai, K.; Montoya-Zavala, M.; Abdollahi, A.; D'Amato, R.; Ingber, D.E. Tumor growth and angiogenesis are dependent on the presence of immature dendritic cells. FASEB J. 2010, 24, 1411-1418. [CrossRef]

67. Gervais, A.; Levêque, J.; Bouet-Toussaint, F.; Burtin, F.; Lesimple, T.; Sulpice, L.; Patard, J.J.; Genetet, N.; Catros-Quemener, V. Dendritic cells are defective in breast cancer patients: A potential role for polyamine in this immunodeficiency. Breast Cancer Res. 2005, 7, R326-R335. [CrossRef]

68. Aspord, C.; Pedroza-Gonzalez, A.; Gallegos, M.; Tindle, S.; Burton, E.C.; Su, D.; Marches, F.; Banchereau, J.; Palucka, A.K. Breast cancer instructs dendritic cells to prime interleukin 13-secreting CD4+ T cells that facilitate tumor development. J. Exp. Med. 2007, 204, 1037-1047. [CrossRef]

69. Chen, X.; Shao, Q.; Hao, S.; Zhao, Z.; Wang, Y.; Guo, X.; He, Y.; Gao, W.; Mao, H. CTLA-4 positive breast cancer cells suppress dendritic cells maturation and function. Oncotarget 2017, 8, 13703-13715. [CrossRef]

70. Treilleux, I.; Blay, J.Y.; Bendriss-Vermare, N.; Ray-Coquard, I.; Bachelot, T.; Guastalla, J.P.; Bremond, A.; Goddard, S.; Pin, J.J.; Barthelemy-Dubois, C.; et al. Dendritic cell infiltration and prognosis of early stage breast cancer. Clin. Cancer Res. 2004, 10, 7466-7474. [CrossRef]

71. da Cunha, A.; Michelin, M.A.; Murta, E.F. Pattern response of dendritic cells in the tumor microenvironment and breast cancer. World J. Clin. Oncol. 2014, 5, 495-502. [CrossRef] [PubMed]

72. Bryson, P.D.; Han, X.; Truong, N.; Wang, P. Breast cancer vaccines delivered by dendritic cell-targeted lentivectors induce potent antitumor immune responses and protect mice from mammary tumor growth. Vaccine 2017, 35, 5842-5849. [CrossRef] [PubMed]

73. Sharma, A.; Koldovsky, U.; Xu, S.; Mick, R.; Roses, R.; Fitzpatrick, E.; Weinstein, S.; Nisenbaum, H.; Levine, B.L.; Fox, K.; et al. HER-2 pulsed dendritic cell vaccine can eliminate HER-2 expression and impact ductal carcinoma in situ. Cancer 2012, 118, 4354-4362. [CrossRef] [PubMed] 
74. Tang, M.; Liu, Y.; Zhang, Q.C.; Zhang, P.; Wu, J.K.; Wang, J.N.; Ruan, Y.; Huang, Y. Antitumor efficacy of the Runx2-dendritic cell vaccine in triple-negative breast cancer in vitro. Oncol. Lett. 2018, 16, 2813-2822. [CrossRef] [PubMed]

75. Bird, R.C.; DeInnocentes, P.; Church Bird, A.E.; Lutful Kabir, F.M.; Martinez-Romero, E.G.; Smith, A.N.; Smith, B.F. Autologous hybrid cell fusion vaccine in a spontaneous intermediate model of breast carcinoma. J. Vet. Sci. 2019, 20, e48. [CrossRef] [PubMed]

76. Zhang, Y.; Luo, W.; Wang, Y.; Chen, J.; Liu, Y.; Zhang, Y. Enhanced antitumor immunity of nanoliposomeencapsulated heat shock protein 70 peptide complex derived from dendritic tumor fusion cells. Oncol. Rep. 2015, 33, 2695-2702. [CrossRef]

77. Avigan, D. Fusions of breast cancer and dendritic cells as a novel cancer vaccine. Clin Breast Cancer 2003, 3 (Suppl. 4), S158-S163. [CrossRef]

78. Gardner, A.; de Mingo Pulido, A.; Ruffell, B. Dendritic Cells and Their Role in Immunotherapy. Front. Immunol. 2020, 11, 924. [CrossRef]

79. Lowenfeld, L.; Mick, R.; Datta, J.; Xu, S.; Fitzpatrick, E.; Fisher, C.S.; Fox, K.R.; DeMichele, A.; Zhang, P.J.; Weinstein, S.P.; et al. Dendritic Cell Vaccination Enhances Immune Responses and Induces Regression of HER2(pos) DCIS Independent of Route: Results of Randomized Selection Design Trial. Clin. Cancer Res. 2017, 23, 2961-2971. [CrossRef]

80. Zhang, W.; Lu, X.; Cui, P.; Piao, C.; Xiao, M.; Liu, X.; Wang, Y.; Wu, X.; Liu, J.; Yang, L. Phase I/II clinical trial of a Wilms' tumor 1-targeted dendritic cell vaccination-based immunotherapy in patients with advanced cancer. Cancer Immunol. Immunother. 2019, 68, 121-130. [CrossRef]

81. Soliman, H.; Khambati, F.; Han, H.S.; Ismail-Khan, R.; Bui, M.M.; Sullivan, D.M.; Antonia, S. A phase-1/2 study of adenovirus-p53 transduced dendritic cell vaccine in combination with indoximod in metastatic solid tumors and invasive breast cancer. Oncotarget 2018, 9, 10110-10117. [CrossRef] [PubMed]

82. Baek, S.; Kim, C.S.; Kim, S.B.; Kim, Y.M.; Kwon, S.W.; Kim, Y.; Kim, H.; Lee, H. Combination therapy of renal cell carcinoma or breast cancer patients with dendritic cell vaccine and IL-2: Results from a phase I/II trial. J. Transl. Med. 2011, 9, 178. [CrossRef] [PubMed]

83. Hodge, J.; Wang, F.; Wang, J.; Liu, Q.; Saaoud, F.; Wang, Y.; Singh, U.P.; Chen, H.; Luo, M.; Ai, W.; et al. Overexpression of microRNA-155 enhances the efficacy of dendritic cell vaccine against breast cancer. Oncoimmunology 2020, 9. [CrossRef]

84. Zhang, M.; Shi, Y.; Zhang, Y.; Wang, Y.; Alotaibi, F.; Qiu, L.; Wang, H.; Peng, S.; Liu, Y.; Li, Q.; et al. miRNA-5119 regulates immune checkpoints in dendritic cells to enhance breast cancer immunotherapy. Cancer Immunol. Immunother. 2020, 69, 951-967. [CrossRef] [PubMed]

85. Taghikhani, A.; Hassan, Z.M.; Ebrahimi, M.; Moazzeni, S.M. microRNA modified tumor-derived exosomes as novel tools for maturation of dendritic cells. J. Cell. Physiol. 2019, 234, 9417-9427. [CrossRef] [PubMed]

86. Oechsle, C.M.; Showalter, L.E.; Novak, C.M.; Czerniecki, B.J.; Koski, G.K. Statin Drugs Plus Th1 Cytokines Potentiate Apoptosis and Ras Delocalization in Human Breast Cancer Lines and Combine with Dendritic Cell-Based Immunotherapy to Suppress Tumor Growth in a Mouse Model of HER-2(pos) Disease. Vaccines 2020, 8, 72. [CrossRef]

87. Showalter, L.E.; Oechsle, C.; Ghimirey, N.; Steele, C.; Czerniecki, B.J.; Koski, G.K. Th1 cytokines sensitize HER-expressing breast cancer cells to lapatinib. PLoS ONE 2019, 14, e0210209. [CrossRef]

88. Xie, Y.; Wu, J.; Xu, A.; Ahmeqd, S.; Sami, A.; Chibbar, R.; Freywald, A.; Zheng, C.; Xiang, J. Heterologous human/rat HER2-specific exosome-targeted T cell vaccine stimulates potent humoral and CTL responses leading to enhanced circumvention of HER2 tolerance in double transgenic HLA-A2/HER2 mice. Vaccine 2018, 36, 1414-1422. [CrossRef]

89. Abdellateif, M.S.; Shaarawy, S.M.; Kandeel, E.Z.; El-Habashy, A.H.; Salem, M.L.; El-Houseini, M.E. A novel potential effective strategy for enhancing the antitumor immune response in breast cancer patients using a viable cancer cell-dendritic cell-based vaccine. Oncol. Lett. 2018, 16, 529-535. [CrossRef]

90. Qi, C.J.; Ning, Y.L.; Han, Y.S.; Min, H.Y.; Ye, H.; Zhu, Y.L.; Qian, K.Q. Autologous dendritic cell vaccine for estrogen receptor (ER)/progestin receptor (PR) double-negative breast cancer. Cancer Immunol. Immunother. 2012, 61, 1415-1424. [CrossRef]

91. Mastelic-Gavillet, B.; Balint, K.; Boudousquie, C.; Gannon, P.O.; Kandalaft, L.E. Personalized Dendritic Cell Vaccines-Recent Breakthroughs and Encouraging Clinical Results. Front. Immunol. 2019, 10, 766. [CrossRef] [PubMed] 
92. Peethambaram, P.P.; Melisko, M.E.; Rinn, K.J.; Alberts, S.R.; Provost, N.M.; Jones, L.A.; Sims, R.B.; Lin, L.R.; Frohlich, M.W.; Park, J.W. A phase I trial of immunotherapy with lapuleucel-T (APC8024) in patients with refractory metastatic tumors that express HER-2/neu. Clin. Cancer Res. 2009, 15, 5937-5944. [CrossRef] [PubMed]

93. Solans, B.P.; Lopez-Diaz de Cerio, A.; Elizalde, A.; Pina, L.J.; Inoges, S.; Espinos, J.; Salgado, E.; Mejias, L.D.; Troconiz, I.F.; Santisteban, M. Assessing the impact of the addition of dendritic cell vaccination to neoadjuvant chemotherapy in breast cancer patients: A model-based characterization approach. Br. J. Clin. Pharmacol. 2019, 85, 1670-1683. [CrossRef]

94. Vasir, B.; Wu, Z.; Crawford, K.; Rosenblatt, J.; Zarwan, C.; Bissonnette, A.; Kufe, D.; Avigan, D. Fusions of dendritic cells with breast carcinoma stimulate the expansion of regulatory $\mathrm{T}$ cells while concomitant exposure to IL-12, CpG oligodeoxynucleotides, and anti-CD3/CD28 promotes the expansion of activated tumor reactive cells. J. Immunol. 2008, 181, 808-821. [CrossRef] [PubMed]

95. Zuo, B.; Qi, H.; Lu, Z.; Chen, L.; Sun, B.; Yang, R.; Zhang, Y.; Liu, Z.; Gao, X.; You, A.; et al. Alarmin-painted exosomes elicit persistent antitumor immunity in large established tumors in mice. Nat. Commun. 2020, 11, 1790. [CrossRef]

96. Lu, H.; Dietsch, G.N.; Matthews, M.A.; Yang, Y.; Ghanekar, S.; Inokuma, M.; Suni, M.; Maino, V.C.; Henderson, K.E.; Howbert, J.J.; et al. VTX-2337 is a novel TLR8 agonist that activates NK cells and augments ADCC. Clin. Cancer Res. 2012, 18, 499-509. [CrossRef]

97. Wick, D.A.; Martin, S.D.; Nelson, B.H.; Webb, J.R. Profound CD8+ T cell immunity elicited by sequential daily immunization with exogenous antigen plus the TLR3 agonist poly(I:C). Vaccine 2011, 29, 984-993. [CrossRef]

98. Di, S.; Zhou, M.; Pan, Z.; Sun, R.; Chen, M.; Jiang, H.; Shi, B.; Luo, H.; Li, Z. Combined Adjuvant of Poly I:C Improves Antitumor Effects of CAR-T Cells. Front. Oncol. 2019, 9, 241. [CrossRef]

99. Glaffig, M.; Stergiou, N.; Schmitt, E.; Kunz, H. Immunogenicity of a Fully Synthetic MUC1 Glycopeptide Antitumor Vaccine Enhanced by Poly(I:C) as a TLR3-Activating Adjuvant. ChemMedChem 2017, 12, 722-727. [CrossRef]

100. Inao, T.; Harashima, N.; Monma, H.; Okano, S.; Itakura, M.; Tanaka, T.; Tajima, Y.; Harada, M. Antitumor effects of cytoplasmic delivery of an innate adjuvant receptor ligand, poly(I:C), on human breast cancer. Breast Cancer Res. Treat. 2012, 134, 89-100. [CrossRef]

101. Fan, L.; Zhou, P.; Hong, Q.; Chen, A.X.; Liu, G.Y.; Yu, K.D.; Shao, Z.M. Toll-like receptor 3 acts as a suppressor gene in breast cancer initiation and progression: A two-stage association study and functional investigation. Oncoimmunology 2019, 8, e1593801. [CrossRef] [PubMed]

102. Schwartz, A.L.; Dickerson, E.; Dagia, N.; Malgor, R.; McCall, K.D. TLR signaling inhibitor, phenylmethimazole, in combination with tamoxifen inhibits human breast cancer cell viability and migration. Oncotarget 2017, 8, 113295-113302. [CrossRef] [PubMed]

103. Hammerich, L.; Marron, T.U.; Upadhyay, R.; Svensson-Arvelund, J.; Dhainaut, M.; Hussein, S.; Zhan, Y.; Ostrowski, D.; Yellin, M.; Marsh, H.; et al. Systemic clinical tumor regressions and potentiation of PD1 blockade with in situ vaccination. Nat. Med. 2019, 25, 814-824. [CrossRef] [PubMed]

104. Lai, J.; Mardiana, S.; House, I.G.; Sek, K.; Henderson, M.A.; Giuffrida, L.; Chen, A.X.Y.; Todd, K.L.; Petley, E.V.; Chan, J.D.; et al. Adoptive cellular therapy with T cells expressing the dendritic cell growth factor Flt3L drives epitope spreading and antitumor immunity. Nat. Immunol. 2020. [CrossRef] [PubMed]

105. Clifton, G.T.; Hale, D.; Vreeland, T.J.; Hickerson, A.T.; Litton, J.K.; Alatrash, G.; Murthy, R.K.; Qiao, N.; Philips, A.V.; Lukas, J.J.; et al. Results of a Randomized Phase IIb Trial of Nelipepimut-S + Trastuzumab versus Trastuzumab to Prevent Recurrences in Patients with High-Risk HER2 Low-Expressing Breast Cancer. Clin. Cancer Res. 2020, 26, 2515-2523. [CrossRef] [PubMed]

106. Clifton, G.T.; Litton, J.K.; Arrington, K.; Ponniah, S.; Ibrahim, N.K.; Gall, V.; Alatrash, G.; Peoples, G.E.; Mittendorf, E.A. Results of a Phase Ib Trial of Combination Immunotherapy with a CD8+ T Cell Eliciting Vaccine and Trastuzumab in Breast Cancer Patients. Ann. Surg Oncol. 2017, 24, 2161-2167. [CrossRef]

107. Clifton, G.T.; Peace, K.M.; Holmes, J.P.; Vreeland, T.J.; Hale, D.F.; Herbert, G.S.; Litton, J.K.; Murthy, R.K.; Lukas, J.; Peoples, G.E.; et al. Initial safety analysis of a randomized phase II trial of nelipepimut-S+ GM-CSF and trastuzumab compared to trastuzumab alone to prevent recurrence in breast cancer patients with HER2 low-expressing tumors. Clin. Immunol. 2019, 201, 48-54. [CrossRef]

108. Mittendorf, E.A.; Lu, B.; Melisko, M.; Price Hiller, J.; Bondarenko, I.; Brunt, A.M.; Sergii, G.; Petrakova, K.; Peoples, G.E. Efficacy and Safety Analysis of Nelipepimut-S Vaccine to Prevent Breast Cancer Recurrence: A Randomized, Multicenter, Phase III Clinical Trial. Clin. Cancer Res. 2019, 25, 4248-4254. [CrossRef] 
109. Pinedo, H.M.; Buter, J.; Luykx-de Bakker, S.A.; Pohlmann, P.R.; van Hensbergen, Y.; Heideman, D.A.; van Diest, P.J.; de Gruijl, T.D.; van der Wall, E. Extended neoadjuvant chemotherapy in locally advanced breast cancer combined with GM-CSF: Effect on tumour-draining lymph node dendritic cells. Eur. J. Cancer 2003, 39, 1061-1067. [CrossRef]

110. Mittendorf, E.A.; Ardavanis, A.; Symanowski, J.; Murray, J.L.; Shumway, N.M.; Litton, J.K.; Hale, D.F.; Perez, S.A.; Anastasopoulou, E.A.; Pistamaltzian, N.F.; et al. Primary analysis of a prospective, randomized, single-blinded phase II trial evaluating the HER2 peptide AE37 vaccine in breast cancer patients to prevent recurrence. Ann. Oncol. 2016, 27, 1241-1248. [CrossRef]

111. Norell, H.; Poschke, I.; Charo, J.; Wei, W.Z.; Erskine, C.; Piechocki, M.P.; Knutson, K.L.; Bergh, J.; Lidbrink, E.; Kiessling, R. Vaccination with a plasmid DNA encoding HER-2/neu together with low doses of GM-CSF and IL-2 in patients with metastatic breast carcinoma: A pilot clinical trial. J. Transl. Med. 2010, 8, 53. [CrossRef] [PubMed]

112. Gasparetto, C.; Gasparetto, M.; Morse, M.; Rooney, B.; Vredenburgh, J.J.; Long, G.D.; Rizzieri, D.A.; Loftis, J.; Chao, N.J.; Smith, C. Mobilization of dendritic cells from patients with breast cancer into peripheral blood stem cell leukapheresis samples using Flt-3-Ligand and G-CSF or GM-CSF. Cytokine 2002, 18, 8-19. [CrossRef]

113. Kim, P.S.; Armstrong, T.D.; Song, H.; Wolpoe, M.E.; Weiss, V.; Manning, E.A.; Huang, L.Q.; Murata, S.; Sgouros, G.; Emens, L.A.; et al. Antibody association with HER-2/neu-targeted vaccine enhances CD8 T cell responses in mice through Fc-mediated activation of DCs. J. Clin. Investig. 2008, 118, 1700-1711. [CrossRef] [PubMed]

114. Lacher, M.D.; Bauer, G.; Fury, B.; Graeve, S.; Fledderman, E.L.; Petrie, T.D.; Coleal-Bergum, D.P.; Hackett, T.; Perotti, N.H.; Kong, Y.Y.; et al. SV-BR-1-GM, a Clinically Effective GM-CSF-Secreting Breast Cancer Cell Line, Expresses an Immune Signature and Directly Activates CD4(+) T Lymphocytes. Front. Immunol. 2018, 9, 776. [CrossRef] [PubMed]

115. Soliman, H.; Mediavilla-Varela, M.; Antonia, S.J. A GM-CSF and CD40L bystander vaccine is effective in a murine breast cancer model. Breast Cancer 2015, 7, 389-397. [CrossRef]

116. Özverel, C.S.; Uyanikgil, Y.; Karaboz, İ.; Nalbantsoy, A. Investigation of the combination of anti-PD-L1 mAb with HER2/neu-loaded dendritic cells and QS-21 saponin adjuvant: Effect against HER2 positive breast cancer in mice. Immunopharmacol. Immunotoxicol. 2020, 1-12. [CrossRef]

117. De Mingo Pulido, Á.; Gardner, A.; Hiebler, S.; Soliman, H.; Rugo, H.S.; Krummel, M.F.; Coussens, L.M.; Ruffell, B. TIM-3 Regulates CD103(+) Dendritic Cell Function and Response to Chemotherapy in Breast Cancer. Cancer Cell 2018, 33, 60-74.e66. [CrossRef]

118. Diamond, J.M.; Vanpouille-Box, C.; Spada, S.; Rudqvist, N.P.; Chapman, J.R.; Ueberheide, B.M.; Pilones, K.A.; Sarfraz, Y.; Formenti, S.C.; Demaria, S. Exosomes Shuttle TREX1-Sensitive IFN-Stimulatory dsDNA from Irradiated Cancer Cells to DCs. Cancer Immunol. Res. 2018, 6, 910-920. [CrossRef]

119. Krombach, J.; Hennel, R.; Brix, N.; Orth, M.; Schoetz, U.; Ernst, A.; Schuster, J.; Zuchtriegel, G.; Reichel, C.A.; Bierschenk, S.; et al. Priming anti-tumor immunity by radiotherapy: Dying tumor cell-derived DAMPs trigger endothelial cell activation and recruitment of myeloid cells. Oncoimmunology 2019, 8, e1523097. [CrossRef] [PubMed]

120. Rodríguez-Ruiz, M.E.; Perez-Gracia, J.L.; Rodríguez, I.; Alfaro, C.; Oñate, C.; Pérez, G.; Gil-Bazo, I.; Benito, A.; Inogés, S.; López-Diaz de Cerio, A.; et al. Combined immunotherapy encompassing intratumoral poly-ICLC, dendritic-cell vaccination and radiotherapy in advanced cancer patients. Ann. Oncol. 2018, 29, 1312-1319. [CrossRef]

121. Gall, V.A.; Philips, A.V.; Qiao, N.; Clise-Dwyer, K.; Perakis, A.A.; Zhang, M.; Clifton, G.T.; Sukhumalchandra, P.; Ma, Q.; Reddy, S.M.; et al. Trastuzumab Increases HER2 Uptake and Cross-Presentation by Dendritic Cells. Cancer Res. 2017, 77, 5374-5383. [CrossRef] [PubMed]

122. Yu, B.; Kusmartsev, S.; Cheng, F.; Paolini, M.; Nefedova, Y.; Sotomayor, E.; Gabrilovich, D. Effective combination of chemotherapy and dendritic cell administration for the treatment of advanced-stage experimental breast cancer. Clin. Cancer Res. 2003, 9, 285-294.

123. Shou, D.; Wen, L.; Song, Z.; Yin, J.; Sun, Q.; Gong, W. Suppressive role of myeloid-derived suppressor cells (MDSCs) in the microenvironment of breast cancer and targeted immunotherapies. Oncotarget 2016, 7, 64505-64511. [CrossRef]

124. Vetsika, E.K.; Koukos, A.; Kotsakis, A. Myeloid-Derived Suppressor Cells: Major Figures that Shape the Immunosuppressive and Angiogenic Network in Cancer. Cells 2019, 8, 1647. [CrossRef] [PubMed] 
125. Kumar, S.; Wilkes, D.W.; Samuel, N.; Blanco, M.A.; Nayak, A.; Alicea-Torres, K.; Gluck, C.; Sinha, S.; Gabrilovich, D.; Chakrabarti, R. DeltaNp63-driven recruitment of myeloid-derived suppressor cells promotes metastasis in triple-negative breast cancer. J. Clin. Investig. 2018, 128, 5095-5109. [CrossRef]

126. Forghani, P.; Waller, E.K. Poly (I: C) modulates the immunosuppressive activity of myeloid-derived suppressor cells in a murine model of breast cancer. Breast Cancer Res. Treat. 2015, 153, 21-30. [CrossRef]

127. Christmas, B.J.; Rafie, C.I.; Hopkins, A.C.; Scott, B.A.; Ma, H.S.; Cruz, K.A.; Woolman, S.; Armstrong, T.D.; Connolly, R.M.; Azad, N.A.; et al. Entinostat Converts Immune-Resistant Breast and Pancreatic Cancers into Checkpoint-Responsive Tumors by Reprogramming Tumor-Infiltrating MDSCs. Cancer Immunol. Res. 2018, 6, 1561-1577. [CrossRef] [PubMed]

128. Geng, F.; Bao, X.; Dong, L.; Guo, Q.Q.; Guo, J.; Xie, Y.; Zhou, Y.; Yu, B.; Wu, H.; Wu, J.X.; et al. Doxorubicin pretreatment enhances $\mathrm{FAP} \alpha /$ survivin co-targeting DNA vaccine anti-tumor activity primarily through decreasing peripheral MDSCs in the 4T1 murine breast cancer model. Oncoimmunology 2020, 9. [CrossRef]

129. Lv, Z.; Zhang, P.; Li, D.; Qin, M.; Nie, L.; Wang, X.; Ai, L.; Feng, Z.; Odhiambo, W.O.; Ma, Y.; et al. CD19-targeting fusion protein combined with PD1 antibody enhances anti-tumor immunity in mouse models. Oncoimmunology 2020, 9. [CrossRef]

130. Ma, H.S.; Poudel, B.; Torres, E.R.; Sidhom, J.W.; Robinson, T.M.; Christmas, B.; Scott, B.; Cruz, K.; Woolman, S.; Wall, V.Z.; et al. A CD40 Agonist and PD-1 Antagonist Antibody Reprogram the Microenvironment of Nonimmunogenic Tumors to Allow T-cell-Mediated Anticancer Activity. Cancer Immunol. Res. 2019, 7, 428-442. [CrossRef]

131. Farsaci, B.; Donahue, R.N.; Coplin, M.A.; Grenga, I.; Lepone, L.M.; Molinolo, A.A.; Hodge, J.W. Immune consequences of decreasing tumor vasculature with antiangiogenic tyrosine kinase inhibitors in combination with therapeutic vaccines. Cancer Immunol. Res. 2014, 2, 1090-1102. [CrossRef] [PubMed]

132. Shi, T.; Song, X.; Wang, Y.; Liu, F.; Wei, J. Combining Oncolytic Viruses With Cancer Immunotherapy: Establishing a New Generation of Cancer Treatment. Front. Immunol. 2020, 11, 683. [CrossRef] [PubMed]

133. Eissa, I.R.; Bustos-Villalobos, I.; Ichinose, T.; Matsumura, S.; Naoe, Y.; Miyajima, N.; Morimoto, D.; Mukoyama, N.; Zhiwen, W.; Tanaka, M.; et al. The Current Status and Future Prospects of Oncolytic Viruses in Clinical Trials against Melanoma, Glioma, Pancreatic, and Breast Cancers. Cancers 2018, 10, 356. [CrossRef] [PubMed]

134. Chaurasiya, S.; Yang, A.; Kang, S.; Lu, J.; Kim, S.I.; Park, A.K.; Sivanandam, V.; Zhang, Z.; Woo, Y.; Warner, S.G.; et al. Oncolytic poxvirus CF33-hNIS-DeltaF14.5 favorably modulates tumor immune microenvironment and works synergistically with anti-PD-L1 antibody in a triple-negative breast cancer model. Oncoimmunology 2020, 9. [CrossRef]

135. Choi, A.H.; O’Leary, M.P.; Lu, J.; Kim, S.I.; Fong, Y.; Chen, N.G. Endogenous Akt Activity Promotes Virus Entry and Predicts Efficacy of Novel Chimeric Orthopoxvirus in Triple-Negative Breast Cancer. Mol. Ther. Oncolytics 2018, 9, 22-29. [CrossRef]

136. Rodriguez Stewart, R.M.; Berry, J.T.L.; Berger, A.K.; Yoon, S.B.; Hirsch, A.L.; Guberman, J.A.; Patel, N.B.; Tharp, G.K.; Bosinger, S.E.; Mainou, B.A. Enhanced Killing of Triple-Negative Breast Cancer Cells by Reassortant Reovirus and Topoisomerase Inhibitors. J. Virol. 2019, 93. [CrossRef]

137. Ghouse, S.M.; Nguyen, H.M.; Bommareddy, P.K.; Guz-Montgomery, K.; Saha, D. Oncolytic Herpes Simplex Virus Encoding IL12 Controls Triple-Negative Breast Cancer Growth and Metastasis. Front. Oncol. 2020, 10, 384. [CrossRef]

138. Lee, T.J.; Nair, M.; Banasavadi-Siddegowda, Y.; Liu, J.; Nallanagulagari, T.; Jaime-Ramirez, A.C.; Guo, J.Y.; Quadri, H.; Zhang, J.; Bockhorst, K.H.; et al. Enhancing Therapeutic Efficacy of Oncolytic Herpes Simplex Virus-1 with Integrin $\beta 1$ Blocking Antibody OS2966. Mol. Cancer Ther. 2019, 18, 1127-1136. [CrossRef]

139. Ye, Z.Q.; Zou, C.L.; Chen, H.B.; Lv, Q.Y.; Wu, R.Q.; Gu, D.N. Folate-conjugated herpes simplex virus for retargeting to tumor cells. J. Gene Med. 2020, e3177. [CrossRef]

140. Xu, W.; Yang, Y.; Hu, Z.; Head, M.; Mangold, K.A.; Sullivan, M.; Wang, E.; Saha, P.; Gulukota, K.; Helseth, D.L., Jr.; et al. LyP-1-Modified Oncolytic Adenoviruses Targeting Transforming Growth Factor $\beta$ Inhibit Tumor Growth and Metastases and Augment Immune Checkpoint Inhibitor Therapy in Breast Cancer Mouse Models. Hum. Gene Ther. 2020. [CrossRef]

141. Yan, Y.; Xu, H.; Wang, J.; Wu, X.; Wen, W.; Liang, Y.; Wang, L.; Liu, F.; Du, X. Inhibition of breast cancer cells by targeting E2F-1 gene and expressing IL15 oncolytic adenovirus. Biosci. Rep. 2019, 39. [CrossRef] [PubMed] 
142. Zhao, H.; Wang, H.; Kong, F.; Xu, W.; Wang, T.; Xiao, F.; Wang, L.; Huang, D.; Seth, P.; Yang, Y.; et al. Oncolytic Adenovirus rAd.DCN Inhibits Breast Tumor Growth and Lung Metastasis in an Immune-Competent Orthotopic Xenograft Model. Hum. Gene Ther. 2019, 30, 197-210. [CrossRef] [PubMed]

143. Bramante, S.; Koski, A.; Liikanen, I.; Vassilev, L.; Oksanen, M.; Siurala, M.; Heiskanen, R.; Hakonen, T.; Joensuu, T.; Kanerva, A.; et al. Oncolytic virotherapy for treatment of breast cancer, including triple-negative breast cancer. Oncoimmunology 2016, 5, e1078057. [CrossRef] [PubMed]

144. Mohamed Amin, Z.; Che Ani, M.A.; Tan, S.W.; Yeap, S.K.; Alitheen, N.B.; Syed Najmuddin, S.U.F.; Kalyanasundram, J.; Chan, S.C.; Veerakumarasivam, A.; Chia, S.L.; et al. Evaluation of a Recombinant Newcastle Disease Virus Expressing Human IL12 against Human Breast Cancer. Sci. Rep. 2019, 9, 13999. [CrossRef] [PubMed]

145. Raihan, J.; Ahmad, U.; Yong, Y.K.; Eshak, Z.; Othman, F.; Ideris, A. Regression of solid breast tumours in mice by Newcastle disease virus is associated with production of apoptosis related-cytokines. BMC Cancer 2019, 19, 315. [CrossRef]

146. Niavarani, S.R.; Lawson, C.; Boudaud, M.; Simard, C.; Tai, L.H. Oncolytic vesicular stomatitis virus-based cellular vaccine improves triple-negative breast cancer outcome by enhancing natural killer and CD8(+) T-cell functionality. J. Immunother. Cancer 2020, 8. [CrossRef]

147. Lal, G.; Rajala, M.S. Combination of Oncolytic Measles Virus Armed With BNiP3, a Pro-apoptotic Gene and Paclitaxel Induces Breast Cancer Cell Death. Front. Oncol. 2018, 8, 676. [CrossRef]

148. McDonald, C.J.; Erlichman, C.; Ingle, J.N.; Rosales, G.A.; Allen, C.; Greiner, S.M.; Harvey, M.E.; Zollman, P.J.; Russell, S.J.; Galanis, E. A measles virus vaccine strain derivative as a novel oncolytic agent against breast cancer. Breast Cancer Res. Treat. 2006, 99, 177-184. [CrossRef]

149. Tai, C.J.; Liu, C.H.; Pan, Y.C.; Wong, S.H.; Tai, C.J.; Richardson, C.D.; Lin, L.T. Chemovirotherapeutic Treatment Using Camptothecin Enhances Oncolytic Measles Virus-Mediated Killing of Breast Cancer Cells. Sci. Rep. 2019, 9, 6767. [CrossRef]

150. Mullins-Dansereau, V.; Petrazzo, G.; Geoffroy, K.; Béland, D.; Bourgeois-Daigneault, M.C. Pre-surgical oncolytic virotherapy improves breast cancer outcomes. Oncoimmunology 2019, 8, e1655363. [CrossRef]

151. Koske, I.; Rossler, A.; Pipperger, L.; Petersson, M.; Barnstorf, I.; Kimpel, J.; Tripp, C.H.; Stoitzner, P.; Banki, Z.; von Laer, D. Oncolytic virotherapy enhances the efficacy of a cancer vaccine by modulating the tumor microenvironment. Int. J. Cancer 2019, 145, 1958-1969. [CrossRef] [PubMed]

152. Liu, W.; Dai, E.; Liu, Z.; Ma, C.; Guo, Z.S.; Bartlett, D.L. In Situ Therapeutic Cancer Vaccination with an Oncolytic Virus Expressing Membrane-Tethered IL-2. Mol. Ther. Oncolytics 2020, 17, 350-360. [CrossRef] [PubMed]

153. Chon, H.J.; Lee, W.S.; Yang, H.; Kong, S.J.; Lee, N.K.; Moon, E.S.; Choi, J.; Han, E.C.; Kim, J.H.; Ahn, J.B.; et al. Tumor Microenvironment Remodeling by Intratumoral Oncolytic Vaccinia Virus Enhances the Efficacy of Immune-Checkpoint Blockade. Clin. Cancer Res. 2019, 25, 1612-1623. [CrossRef] [PubMed]

154. Feola, S.; Capasso, C.; Fusciello, M.; Martins, B.; Tahtinen, S.; Medeot, M.; Carpi, S.; Frascaro, F.; Ylosmaki, E.; Peltonen, K.; et al. Oncolytic vaccines increase the response to PD-L1 blockade in immunogenic and poorly immunogenic tumors. Oncoimmunology 2018, 7, e1457596. [CrossRef]

155. Guo, Z.S.; Lu, B.; Guo, Z.; Giehl, E.; Feist, M.; Dai, E.; Liu, W.; Storkus, W.J.; He, Y.; Liu, Z.; et al. Vaccinia virus-mediated cancer immunotherapy: Cancer vaccines and oncolytics. J. Immunother. Cancer 2019, 7, 6. [CrossRef]

156. Bourgeois-Daigneault, M.C.; Roy, D.G.; Aitken, A.S.; El Sayes, N.; Martin, N.T.; Varette, O.; Falls, T.; St-Germain, L.E.; Pelin, A.; Lichty, B.D.; et al. Neoadjuvant oncolytic virotherapy before surgery sensitizes triple-negative breast cancer to immune checkpoint therapy. Sci. Transl. Med. 2018, 10. [CrossRef]

157. Andtbacka, R.H.; Kaufman, H.L.; Collichio, F.; Amatruda, T.; Senzer, N.; Chesney, J.; Delman, K.A.; Spitler, L.E.; Puzanov, I.; Agarwala, S.S.; et al. Talimogene Laherparepvec Improves Durable Response Rate in Patients With Advanced Melanoma. J. Clin. Oncol. 2015, 33, 2780-2788. [CrossRef]

158. Feng, X.; Liu, H.; Chu, X.; Sun, P.; Huang, W.; Liu, C.; Yang, X.; Sun, W.; Bai, H.; Ma, Y. Recombinant virus-like particles presenting IL-33 successfully modify the tumor microenvironment and facilitate antitumor immunity in a model of breast cancer. Acta Biomater. 2019, 100, 316-325. [CrossRef]

159. Wang, Q.; Yang, M.; Zhang, Y.; Zhong, L.; Zheng, X. Novel Combination Oncolytic Adenoviral Gene Therapy Armed with Dm-dNK and CD40L for Breast Cancer. Curr. Gene Ther. 2019, 19, 54-65. [CrossRef] 
160. Schenkel, A.R.; Chew, T.W.; Muller, W.A. Platelet endothelial cell adhesion molecule deficiency or blockade significantly reduces leukocyte emigration in a majority of mouse strains. J. Immunol. 2004, 173, 6403-6408. [CrossRef]

161. Sokeland, G.; Schumacher, U. The functional role of integrins during intra- and extravasation within the metastatic cascade. Mol. Cancer 2019, 18, 12. [CrossRef] [PubMed]

162. Stoletov, K.; Kato, H.; Zardouzian, E.; Kelber, J.; Yang, J.; Shattil, S.; Klemke, R. Visualizing extravasation dynamics of metastatic tumor cells. J. Cell Sci. 2010, 123, 2332-2341. [CrossRef] [PubMed]

163. Fukumura, D.; Kloepper, J.; Amoozgar, Z.; Duda, D.G.; Jain, R.K. Enhancing cancer immunotherapy using antiangiogenics: opportunities and challenges. Nat. Rev. Clin. Oncol. 2018, 15, 325-340. [CrossRef] [PubMed]

164. Garcia, J.; Hurwitz, H.I.; Sandler, A.B.; Miles, D.; Coleman, R.L.; Deurloo, R.; Chinot, O.L. Bevacizumab $(\operatorname{Avastin}(\mathrm{R}))$ in cancer treatment: A review of 15 years of clinical experience and future outlook. Cancer Treat. Rev. 2020, 86. [CrossRef]

165. Loges, S.; Schmidt, T.; Carmeliet, P. Mechanisms of resistance to anti-angiogenic therapy and development of third-generation anti-angiogenic drug candidates. Genes Cancer 2010, 1, 12-25. [CrossRef]

166. Kangsamaksin, T.; Murtomaki, A.; Kofler, N.M.; Cuervo, H.; Chaudhri, R.A.; Tattersall, I.W.; Rosenstiel, P.E.; Shawber, C.J.; Kitajewski, J. NOTCH decoys that selectively block DLL/NOTCH or JAG/NOTCH disrupt angiogenesis by unique mechanisms to inhibit tumor growth. Cancer Discov. 2015, 5, 182-197. [CrossRef]

167. Wei, Y.Q.; Wang, Q.R.; Zhao, X.; Yang, L.; Tian, L.; Lu, Y.; Kang, B.; Lu, C.J.; Huang, M.J.; Lou, Y.Y.; et al. Immunotherapy of tumors with xenogeneic endothelial cells as a vaccine. Nat. Med. 2000, 6, 1160-1166. [CrossRef]

168. Wagner, S.C.; Ichim, T.E.; Ma, H.; Szymanski, J.; Perez, J.A.; Lopez, J.; Bogin, V.; Patel, A.N.; Marincola, F.M.; Kesari, S. Cancer anti-angiogenesis vaccines: Is the tumor vasculature antigenically unique? J. Transl. Med. 2015, 13, 340. [CrossRef] [PubMed]

169. Yan, H.X.; Cheng, P.; Wei, H.Y.; Shen, G.B.; Fu, L.X.; Ni, J.; Wu, Y.; Wei, Y.Q. Active immunotherapy for mouse breast cancer with irradiated whole-cell vaccine expressing VEGFR2. Oncol. Rep. 2013, 29, 1510-1516. [CrossRef]

170. Lu, M.; Yao, Q.; Liu, H.; Zhong, W.; Gao, J.; Si, C.; Zhou, L.; Zhang, S.; Xu, M. Combination of Human Umbilical Vein Endothelial Cell Vaccine and Docetaxel Generates Synergistic Anti-Breast Cancer Effects. Cancer Biother. Radiopharm. 2019, 34, 464-471. [CrossRef] [PubMed]

171. Zhao, X.; Bose, A.; Komita, H.; Taylor, J.L.; Chi, N.; Lowe, D.B.; Okada, H.; Cao, Y.; Mukhopadhyay, D.; Cohen, P.A.; et al. Vaccines targeting tumor blood vessel antigens promote CD8(+) T cell-dependent tumor eradication or dormancy in HLA-A2 transgenic mice. J. Immunol. 2012, 188, 1782-1788. [CrossRef]

172. Lu, Y.; Wei, Y.Q.; Tian, L.; Zhao, X.; Yang, L.; Hu, B.; Kan, B.; Wen, Y.J.; Liu, F.; Deng, H.X.; et al. Immunogene therapy of tumors with vaccine based on xenogeneic epidermal growth factor receptor. J. Immunol. 2003, 170, 3162-3170. [CrossRef]

173. Jin, D.; Yu, X.; Chen, B.; Li, Z.; Ding, J.; Zhao, X.; Qi, G. Combined immunotherapy of breast cancer with EGF and VEGF vaccines from DNA shuffling in a mouse model. Immunotherapy 2017, 9, 537-553. [CrossRef]

174. Wood, L.M.; Pan, Z.K.; Guirnalda, P.; Tsai, P.; Seavey, M.; Paterson, Y. Targeting tumor vasculature with novel Listeria-based vaccines directed against CD105. Cancer Immunol. Immunother. 2011, 60, 931-942. [CrossRef]

175. Lee, S.H.; Mizutani, N.; Mizutani, M.; Luo, Y.; Zhou, H.; Kaplan, C.; Kim, S.W.; Xiang, R.; Reisfeld, R.A. Endoglin (CD105) is a target for an oral DNA vaccine against breast cancer. Cancer Immunol. Immunother. 2006, 55, 1565-1574. [CrossRef] [PubMed]

176. Kaplan, C.D.; Kruger, J.A.; Zhou, H.; Luo, Y.; Xiang, R.; Reisfeld, R.A. A novel DNA vaccine encoding PDGFRbeta suppresses growth and dissemination of murine colon, lung and breast carcinoma. Vaccine 2006, 24, 6994-7002. [CrossRef]

177. Seavey, M.M.; Maciag, P.C.; Al-Rawi, N.; Sewell, D.; Paterson, Y. An anti-vascular endothelial growth factor receptor 2/fetal liver kinase-1 Listeria monocytogenes anti-angiogenesis cancer vaccine for the treatment of primary and metastatic Her-2/neu+ breast tumors in a mouse model. J. Immunol. 2009, 182, 5537-5546. [CrossRef]

178. Xie, K.; Bai, R.Z.; Wu, Y.; Liu, Q.; Liu, K.; Wei, Y.Q. Anti-tumor effects of a human VEGFR-2-based DNA vaccine in mouse models. Genet Vaccines Ther. 2009, 7, 10. [CrossRef] [PubMed] 
179. Denies, S.; Leyman, B.; Huysmans, H.; Combes, F.; Mc Cafferty, S.; Cicchelero, L.; Steppe, M.; De Temmerman, J.; Sanders, N.N. Evaluation of a xenogeneic vascular endothelial growth factor-2 vaccine in two preclinical metastatic tumor models in mice. Cancer Immunol. Immunother. 2017, 66, 1545-1555. [CrossRef] [PubMed]

180. Zhang, H.; Jia, E.; Xia, W.; Lv, T.; Lu, C.; Xu, Z.; Zhu, W. Utilizing VEGF165b mutant as an effective immunization adjunct to augment antitumor immune response. Vaccine 2019, 37, 2090-2098. [CrossRef] [PubMed]

181. Jambusaria, A.; Hong, Z.; Zhang, L.; Srivastava, S.; Jana, A.; Toth, P.T.; Dai, Y.; Malik, A.B.; Rehman, J. Endothelial heterogeneity across distinct vascular beds during homeostasis and inflammation. Elife 2020, 9. [CrossRef] [PubMed]

182. Cleuren, A.C.A.; van der Ent, M.A.; Jiang, H.; Hunker, K.L.; Yee, A.; Siemieniak, D.R.; Molema, G.; Aird, W.C.; Ganesh, S.K.; Ginsburg, D. The in vivo endothelial cell translatome is highly heterogeneous across vascular beds. Proc. Natl. Acad. Sci. USA 2019, 116, 23618-23624. [CrossRef] [PubMed]

183. Del Valle, P.R.; Milani, C.; Brentani, M.M.; Katayama, M.L.; de Lyra, E.C.; Carraro, D.M.; Brentani, H.; Puga, R.; Lima, L.A.; Rozenchan, P.B.; et al. Transcriptional profile of fibroblasts obtained from the primary site, lymph node and bone marrow of breast cancer patients. Genet Mol. Biol. 2014, 37, 480-489. [CrossRef]

184. Kieffer, Y.; Hocine, H.R.; Gentric, G.; Pelon, F.; Bernard, C.; Bourachot, B.; Lameiras, S.; Albergante, L.; Bonneau, C.; Guyard, A.; et al. Single-cell analysis reveals fibroblast clusters linked to immunotherapy resistance in cancer. Cancer Discov. 2020. [CrossRef]

185. Hu, M.; Yao, J.; Cai, L.; Bachman, K.E.; van den Brûle, F.; Velculescu, V.; Polyak, K. Distinct epigenetic changes in the stromal cells of breast cancers. Nat. Genet. 2005, 37, 899-905. [CrossRef]

186. Orimo, A.; Gupta, P.B.; Sgroi, D.C.; Arenzana-Seisdedos, F.; Delaunay, T.; Naeem, R.; Carey, V.J.; Richardson, A.L.; Weinberg, R.A. Stromal fibroblasts present in invasive human breast carcinomas promote tumor growth and angiogenesis through elevated SDF-1/CXCL12 secretion. Cell 2005, 121,335-348. [CrossRef]

187. Xia, Q.; Zhang, F.F.; Geng, F.; Liu, C.L.; Xu, P.; Lu, Z.Z.; Yu, B.; Wu, H.; Wu, J.X.; Zhang, H.H.; et al. Anti-tumor effects of DNA vaccine targeting human fibroblast activation protein alpha by producing specific immune responses and altering tumor microenvironment in the 4T1 murine breast cancer model. Cancer Immunol. Immunother. 2016, 65, 613-624. [CrossRef]

188. Xia, Q.; Geng, F.; Zhang, F.F.; Liu, C.L.; Xu, P.; Lu, Z.Z.; Xie, Y.; Sun, B.; Wu, H.; Yu, B.; et al. Cyclophosphamide enhances anti-tumor effects of a fibroblast activation protein $\alpha$-based DNA vaccine in tumor-bearing mice with murine breast carcinoma. Immunopharmacol. Immunotoxicol. 2017, 39, 37-44. [CrossRef] [PubMed]

189. Geng, F.; Guo, J.; Guo, Q.Q.; Xie, Y.; Dong, L.; Zhou, Y.; Liu, C.L.; Yu, B.; Wu, H.; Wu, J.X.; et al. A DNA vaccine expressing an optimized secreted FAPalpha induces enhanced anti-tumor activity by altering the tumor microenvironment in a murine model of breast cancer. Vaccine 2019, 37, 4382-4391. [CrossRef] [PubMed]

190. Achyut, B.R.; Zhang, H.; Angara, K.; Mivechi, N.F.; Arbab, A.S.; Ko, L. Oncoprotein GT198 vaccination delays tumor growth in MMTV-PyMT mice. Cancer Lett. 2020, 476, 57-66. [PubMed]

191. Sung Kim, T.; Cohen, E.P. Immunity to breast cancer in mice immunized with fibroblasts transfected with a cDNA expression library derived from small numbers of breast cancer cells. Cancer Gene Ther. 2005, 12, 890-899. [CrossRef] [PubMed]

192. Kim, T.S.; Jung, M.Y.; Cho, D.; Cohen, E.P. Prolongation of the survival of breast cancer-bearing mice immunized with GM-CSF-secreting syngeneic/allogeneic fibroblasts transfected with a cDNA expression library from breast cancer cells. Vaccine 2006, 24, 6564-6573. [CrossRef]

(C) 2020 by the authors. Licensee MDPI, Basel, Switzerland. This article is an open access article distributed under the terms and conditions of the Creative Commons Attribution (CC BY) license (http://creativecommons.org/licenses/by/4.0/). 